Original Article

\section{Effect of Musa sapientum (Banana) on Indomethacin-Induced Gastric Mucosal Injury in Rats: Histological Study}

\author{
Safaa S. Ali, Reham I. ElGibaly and Safaa A. Abdel-Maksoud
}

Histology Department, Faculty of Medicine, Assuit University

\begin{abstract}
Background: Non-steroidal anti-inflammatory drugs (NSAIDs) are the most commonly prescribed drugs. Gastric injury is the most common side effects of NSAIDs .It develops in 30\% of all chronic NSAIDS users. It has many complications as bleeding and perforation. Drugs used in gastric treatment induce side effects, relapses and drug interactions. Banana is a common tropical plant that has been consumed since centuries.

Objective: To investigate the role of banana in prevention and treatment of NSAID-induced gastric injury.

Material \& methods: 48 adult male albino rats were divided into 6 groups; GroupI received water, GroupII received banana $7 \mathrm{gm} / \mathrm{kg} 3$ times /day for 2 days, GroupIII received indomethacin $(100 \mathrm{mg} / \mathrm{kg})$ once, GroupIV received indomethacin once then left for 2 days, GroupV received Indomethacin once with banana for 2 days, GroupVI received Indomethacin once then banana for 2 days. Rats were sacrificed; and stomach was processed for histological, immunohistochemical and morphometric studies.

Results: indomethacin group(III) showed mucosal lesions, hemorrhagic streaks, desquamation of surface epithelium, loss of normal glandular architecture and degenerative changes in the mucous and parietal cells. Autohealing group(IV) showed delayed healing. Prevented group(V) showed less mucosal lesions. However, treated group(VI) showed more or less normal mucosa. Statistically, significant decrease in enteroendocrine cells, Proliferating Cell Nuclear Antigen (PCNA) -positive cells and Vascular Endothelial Growth Factor (VEGF) expression in indomethacin group, with significant increase in in treated group compared with other groups.

Conclusion: Banana accelerated healing in Indomethacin-induced injury of gastric mucosa and its therapeutic effect was more effective than its prophylactic one.
\end{abstract}

Key Words: Banana, gastric mucosa, indomethacin, PCNA, VEGF.

Revised: 15 July 2018, Accepted: 2 October 2018

Corresponding Author: Safaa S. Ali, Histology Department, Faculty of Medicine, Assuit University, Egypt, Tel.: +2 01090067886, E-mail: hassan.safaa@yahoo.com.

ISSN: 1110-0559, Vol. 2, No. 1

\section{INTRODUCTION}

Gastric injury is one of the most common gastrointestinal disorders that affects $5 \%$ of the population around the world ${ }^{(1)}$. It results from imbalance between aggressive and defensive factors. The aggressive factors include exogenous factors such as alcohol, non-steroidal anti-inflammatory drugs (NSAIDs), H. pylori, and psychological stress. as well as endogenous factors such as HCL, pepsine, bile and reactive oxygen species. The cytoprotective intrinsic factors include mucosal blood flow, growth factors, mucous cell renewal, mucousbicarbonate barrier, nitric oxide (NO) and prostaglandins (PGs) $)^{(1)}$.

NSAIDs such as indomethacin are one of the most commonly used drugs. They are commonly used for treatment of many clinical conditions such as inflammation and relieving pain. They are also used in colorectal cancer, cardiovascular diseases, rheumatoid arthritis, osteoarthritis and many other diseases. As being widely used, it would be impossible to avoid their side effects. NSAIDs have many gastrointestinal adverse effects. Gastric damage is considered the most common and dangerous side effects of these drugs. It accounts for about $25 \%$ of gastric ulcer cases. Gastric ulcer is considered the fourth disease causing morbidity and mortality in the world ${ }^{(2)}$.

Many drugs are availabe for gastric ulcer treatment including drugs which decrease gastric acid secretion like H2-receptor blockers (ranitidine), M1 blockers (pirenzepine) and proton pump inhibitors (omeperazole) Other drugs like carbenoxolone enhances mucosal defense. Although these drugs have a remarkable improvement in ulcer therapy, their efficacy is still debatable due to the high incidence of relapses, side effects and danger of drug interactions during therapy. They are also expensive for long term use ${ }^{(3)}$. Therefore, the search for ideal efficient antiulcer drug with less or no side effect has become mandatory. The search for new antiulcer drug has extended to herbal plants because the first effective drug against gastric ulcer was carbenoxolone which is isolated from plant (licorice) $)^{(2)}$. The World Health Organization (WHO) reported that about most of the world's population use herbal plants in treatment of many diseases and 
maintainance of health because of their availability, high safety and low $\operatorname{cost}^{(3)}$.

Musa sapientum (plantain banana) is a very common large evergreen tree worldwilde. Banana is rich in potassium, vitamins (A, B6, C and D ) and carbohydrate $^{(4)}$. Many studies, carried on plantian banana, showed that it has many bioactivities such as antioxidant, antihypertensive, antibacterial, antifungal, diuretic and bronchodilator $^{(5)}$. It is also used in treatment of depression, premenstrual syndrome, anemia and constipation ${ }^{(4)}$. Plantain banana, also has healing abilities in treatment of skin infections, rashes and wounds, so it is considered as a "green bandage"(6).

Therefore, the aim of the present study was to evaluate the possible preventive and curative effects of unripen plantain banana against indomethacin-induced gastric mucosal injury in rats and investigate the possible mechanisms of banana healing effect.

\section{MATERIAL AND METHODS}

\section{Materials}

-Indomethacin (Liometacen \& Chiesi Farmaceutici) was purchased from the pharmacy in a form of powder in ampules of $50 \mathrm{mg}$. It was given orally dissolved in normal saline as a single dose of $100 \mathrm{mg} / \mathrm{kg}^{(7)}$.

- Vegetable plantain banana was purchased from local market. Skin from each unripen green banana fruit was peeled off and pulp was cut into thin slices. These slices were spread and dried in sunlight. The dried banana slices were then ground to get the powder. Banana powder was dissolved in water $(7 \mathrm{~g} / \mathrm{kg})$ and used ${ }^{(5)}$.

- Rabbit Polyclonal Anti- PCNA (Proliferating Cell Nuclear Antigen) antibody was purchased from Chongqing Biospes Co. (Chongqing, China), Catalogue number YPA1100.

- Rabbit Polyclonal Anti- VEGF antibody (Vascular Endothelial Growth Factor) was purchased from Chongqing Biospes Co. (Chongqing, China), Catalogue number YPA1071.

\section{Animals:}

Forty eight adult male albino rats (5 months old, weighting 150250- g) were used and maintained in the animal house of Faculty of Medicine, Assiut University, Egypt. They were housed in clean cages, at appropriate temperature and provided with water and fed rat chow. The animals were fasted for 24 hour before the experiment, with free access to water. All experimental animal procedures were approved by the Institutional Ethics Committee of Faculty of Medicine, Assiut University, Egypt.

\section{Experimental design:}

The animals were randomly divided into 6 equal groups ( 8 rats each): Group I (control) had free access to water for two successive days, as a negative control group. Group II (banana only) received only oral banana
$7 \mathrm{gm} / \mathrm{kg}, 3$ times /day for two successive days. Group III (indomethacin) received indomethacin orally $100 \mathrm{mg} / \mathrm{kg}$ once and sacrificed 5 hours later. Group IV (autohealing) received indomethacin orally $100 \mathrm{mg} / \mathrm{kg}$ once and left for 2 days then sacrificed. Group V (prevented) received indomethacin orally $100 \mathrm{mg} / \mathrm{kg}$ once with banana $7 \mathrm{gm} /$ $\mathrm{kg}, 3$ times /day for two successive days. Group VI (treated) received indomethacin orally $100 \mathrm{mg} / \mathrm{kg}$ once and after 5 hours they were given oral banana $7 \mathrm{gm} / \mathrm{kg}, 3$ times /day for 2 successive days ${ }^{(5)}$.

The rats were sacrificed; their stomach was dissected out and washed with normal saline. Stomach was opened along greater curvature starting from rumenal end and proceeding to pyloric end.

\section{Gross examination:}

The stomach was stretched with mucosal surface up and examined grossly by a dissecting microscope (Olympus stereo tri-nocular microscop, Tokyo, Japan) at (X10 magnification) and digital images were captured.

\section{Light microscopic study:}

Specimens from the fundic regions of the stomach were fixed in $10 \%$ buffered formalin, dehydrated and embedded in paraffin, sectioned at $(5 \mu \mathrm{m})$ thickness and stained with Haematoxylin and Eosin (H\&E), Periodic Acid Schiff (PAS) and double silver impregnation modification of Pascual ${ }^{(8)}$.

\section{Immunohistochemical study:}

The immunohistochemical staining of PCNA and VEGF in the gastric mucosa of rats was performed. Paraffin embedded sections were deparaffinized in xylene and rehydrated in alcohol. Endogenous peroxidase was blocked with $\mathrm{H} 2 \mathrm{O} 2$ for 30 minutes. After 3 rinses in phosphate buffered saline (PBS) (0.01 mol/L, pH7.4), the sections were incubated overnight with the polyclonal anti- PCNA antibody $(1: 300)$ and the polyclonal antiVEGF antibody $(1: 300)$ at $4^{\circ} \mathrm{C}$. After 3 rinses in PBS, the sections were incubated for 1 hour with secondary antibody and washed again with PBS. The reaction was visualized using diaminobenzidine (DAB) solution containing $0.01 \% \mathrm{H} 2 \mathrm{O} 2$ in PBS as a chromogen for staining PCNA (nuclear reaction) and VEGF (cytoplasmic reaction) then rinse in PBS. Finally, the sections were counterstained with Mayer's hematoxylin, dehydrated and mounted. For negative controls, the sections were processed without the primary antibody ${ }^{(8)}$.

\section{Electron microscopic study:}

Specimens from the fundic mucosa were fixed in $2.5 \%$ phosphate buffered glutaraldehyde for 2 hours and post fixed in $1 \%$ buffered osmium tetroxide for one hour, then the specimens were dehydrated and embedded. Ultrathin sections were examined using the transmission electron microscope (Jeol E.M.-100 CX11; Japanese electron optic laboratory, Tokyo, Japan) and photographed at Assuit University Electron Microscope Unit ${ }^{(9)}$. 


\section{Morphometric study:}

-The following parameters were measured using the image analyzer Leica Qwin 500 program) Germany):

(i) The mean number of enteroendocrine cells stained by double silver impregnation of Pascaul;

(ii) The mean number of PCNA-positive nuclei.

- The mean gray was used for measurement of the optical density of VEGF immunoreaction using imageJ ${ }^{\circledR}$ software (National Institutes of Health, Bethesda, USA). Five slides were used for each group. All parameters were measured in randomly selected five non-overlapping fields per slide, at 400x magnification in the fundic gland. Calculations were performed using SPSS (ANOVA test) (version 17; SPSS Inc., Chicago, Illinois, USA). The results were expressed as mean $\pm \mathrm{SD}$ (standard deviation). $\mathrm{P}$ value was considered significant if less than $0.05^{(10)}$.

\section{RESULTS}

On examination of sections of the different stains and techniques, the fundus of the stomach of banana only group showed a picture similar to that of the control group.

\section{Gross examination:}

By gross examination, the stomach of control group showed that the non glandular part of the mucosa of the forestomach (near the oseophageal end) had a whitish colour. The glandular part had dark colour and prominent rugae (Fig.1A). Gastric mucosa of indomethacin group showed apparent hyperaemia, hemorrhagic streak and macroscopic mucosal lesions of different sizes, shapes and colours ranging from hyperaemia to dark brown lesions (Fig.1B). In autohealing group ,2 days after indomethacin, the gastric mucosa still showing hyperaemia, hemorrhagic streak and macroscopic mucosal lesions of different sizes and shapes (Fig.1C). In prevented group there was mild hyperaemia and few dark brown lesion in glandular part (Fig.1D). Treated group showed apparent more or less normal glandular mucosa with prominent rugae. Only one small brownish lesion was observed (Fig.1E).

\section{Light microscopic results:}

\section{A) Hematoxylin and Eosin stain (H\&E)}

Examination of the stomach sections of control group showed the gastric mucosa, submucosa and muscularis externa (Fig.2A). The surface epithelial cells were columnar, acidophilic with oval basal vesicular nuclei. The gastric pits were short, narrow and lined by columnar surface mucous cells. The fundic glands had normal glandular architecture. They were lined by mucous secreting cells and parietal cells. Mucous neck cells had pale foamy acidophilic cytoplasm and flat basal nuclei. Parital cells appeared large polyhedral with deep acidophilic cytoplasm and central, rounded vesicular nuclei (Fig.3A).

Indomethacin group revealed variable degrees of focal mucosal damage. Surface epithelial cells were partially desquamated with some shedded cells in the lumen. The gastric glands lost their normal architecture and cellular arrangment. Thickening of lower part of mucosa with extension into muscularis externa was observed (Fig. 2B). The desquamated cells were shrinked with deeply stained cytoplasm and pyknotic nuclei. Gastric pits appeared wide. Mucous neck cells and parietal cells had vacuolated cytoplasm and pyknotic nuclei (Fig. 3B).

Autohealing group showed persistent focal mucosal damage. Some surface epithelial cells were desquamated. They were shrinked with deeply stained cytoplasm and pyknotic nuclei. The gastric glands had irregular cellular arrangment. Granulation tissue appeared in the lesion area (Fig.2C). Mucous neck cells and parietal cells had vacuolated cytoplasm and pyknotic nuclei. Granulation tissue appeared in the lesion area (Fig.3C).

Prevented group showed mild desquamation of surface epithelial cells with some shedded cells in the lumen. The cells lining the glands appeared less damaged than in indomethacin group (Fig. 2D). The surface epithelial cells were apparently normal but some cells were shrinked and shedded with deep acidophilic cytoplasm and basal dense nuclei. Mucous neck cells appeared normal with some vacuolation of their cytoplasm .Some parietal cells appeared normal, while other cells had vacuolated cytoplasm and pyknotic nuclei (Fig. 3D).

Treated group revealed normal mucosal structure comparable with that in the control group. The mucosa appeared intact with short narrow pits and regularly arranged fundic glands (Fig.2E). Predominant active surface mucous cells appeared intact with basal oval vesicular nuclei and pale acidophilic cytoplasm. Mucous neck cells appeared intact. Parietal cells appeared with central rounded vesicular nuclei and acidophilic cytoplasm, while some cells showed mild vacuolation and pyknotic nuclei (Fig.3E).

\section{B)Periodic Acid Schiff stain :}

PAS stained sections of control group showed highly positive PAS reaction in form of thick magenta red mucous film in the surface epithelium and gastric pits (Fig.4A) . Indomethacin group revealed marked reduction in PASpositive reactions with interrupted loss of PAS reaction over the surface epithelium of the damaged area (Fig.4B). Autohealing group showed faint thin PAS positive reaction of surface mucous film in some areas. Other damaged areas showed loss of PAS reaction over surface epithelium (Fig.4C). Prevented group showed moderate PAS positive reaction of surface mucous film in some areas. Other damaged areas showed loss of PAS reaction over surface epithelium (Fig.4D). Treated group, showed continous slightly thick PAS positive reaction of surface mucous film. It extended into the gastric pits (Fig.4E).

\section{C) Double silver impregnation modification of Pascual:}

The modified method for double silver impregnation of Pascual showed positive reaction for enteroendocrine cells in gastric glands. In control group, the enteroendocrine cells were identified by the presence of brown to black 
secretory granules (Fig.5A). In indomethacin group, the enteroendocrine cells apparently decreased. They appeared with faint brown secretory granules (Fig. 5B). Autohealing group showed few amount of the enteroendocrine cells with faint brown secretory granules (Fig.5C). Prevented group showed that the enteroendocrine cells were apparently slightly increased in comparison with group III.Their secretory granules were apparently normal compared to control group (Fig.5D). While in treated group the enteroendocrine cells were as similar as control group. They appeared with dense brown secretory granules (Fig.5E).

\section{(D) Immunohistochemical Results:}

Immunohistochemical staining for PCNA, the control group showed PCNA positive nuclei in the cells of the fundic glands (Fig. 6A). Indomethacin group showed an apparent few PCNA-positive cells as compared with that in the control group (Fig. 6B). In autohealing group ,there was slight increase in the PCNA-positive cells as compared with that in the indomethacin group (Fig. 6C). Prevented group showed moderate increase in the PCNA-positive cells as compared with that in the indomethacin group (Fig. 6D). Treated group showed numerous PCNA-positive cells comparable with that in the other groups (Fig. 6E).

Immunohistochemical staining for VEGF, control group showed positive cytoplasmic VEGF reaction (Fig.7A). Indomethacin group showed decreased in VEGF positive reaction as compared with that in the control group (Fig.7B). In autohealing group ,there was mild positive VEGF reaction (Fig.7C). Prevented group showed moderate VEGF positive reaction (Fig.7D), while treated group showed a strong positive reaction compared to the other groups (Fig.7E).

\section{Electron microscopic examination :}

Electron microscopic examination of the mucosa of control group showed, Mucous secreting cells with apical electron lucent mucous secreting granules in different shapes and sizes, euchromatic nucleus with prominent nucleoli and regular distributed dense heterochromatin. The mitochondria were distributed in the cytoplasm with transverse regular cristae. Rough endoplasmic reticulum and ribosomes were found in the cytoplasmic matrix. Microvilli were projecting from the luminal surface. Also tight junctions between cells were observed (Fig .8A). The Parietal cells had centraly located euchroamtic nuclei with prominent nucleolus. There was extensive tubulovesicular system in the cytoplasm. Characteristic numerous mitochondria were observed in lateral and basal borders of the cells and near to the nuclei. Intracellular canaliculi were observed continous with microvilli. The cytoplasmic matrix contained numerous ribosomes and well-developed tubulovesicles (Fig .8B).

Indomethacin group showed variable degrees of cellular damage and wide spaces between cells. Mucous secreting cells showed disrupted cell membrane, irregualr nuclear membrane with dense clumps of heterochromatin. The cytoplasm was vacuolated with some dense bodies. The apical mucous granules were disrupted. Mitochondria were destroyed, variable in size with irregular cristae. Rough endoplasmic reticulum was dilated (Fig.9A). Parietal cell showed marked dilatation of intracellular canaliculi and luminal debris of microvilli. The nucleus was irregular and small. Cytoplasm was vacuolated. Mitochondria were irregular in size and markedly destroyed with irregular cristae (Fig.9B).

Prevented group showed apparent less damage compared to indomethacin group. Mucous secreting cells had microvilli and few mucous granules. Nucleus with dense clumps of heterochromatin and prominent nucleolus were observed. Some mitochondria were irregular. Rough endoplasmic reticulum and ribosomes were intact (Fig.10A). Parietal cell showed vacuolated cytoplasm and normal nucleus with prominent nulceolus and regular nuclear envelope. Intracellular canaliculi appeared dilated. Mitochondria were numerous but some of them were disrupted with irregular cristae (Fig. 10B).

Treated group showed more or less normal cells .Mucous secreting cell showed oval regular nucleus with regular arranged heterochromatin and prominent nucleolus. Numerous mucous secreting granules were observed with different sizes and electron densities. Microvilli were observed (Fig.11A). Parietal cells showed regular euchromatic nucleus with regular nuclear membrane and regular arrangment of chromatin. Mitochondria were numerous with regular intact cristae. Mild dilated intracellular canaliculi were observed (Fig.11B).

\section{Morphometric and statistical results:}

-Statistical analysis showed that in indomethacin group there was significant decrease in the number of enteroendocrine cells compared to control group. Autohealing group showed mild significant increase as compared to indomethacin group. A significant increase in number of the cells in prevented and treated groups was noticed in comparison to indomethacin group. A highly signifinant increase in the mean cell number in treated group as compared to prevented group was noticed. In treated group there was insignificant difference in number of enteroendocrine cells compared to control group (Table $1 \&$ Histogram 1).

- The mean number of PCNA-positive cells was insignificantly decreased in indomethacin group and increased in autohealing group. Prevented and treated groups showed a highly significant increase in comparison to indomethacin (Table $2 \&$ Histogram 2).

- Statistical analysis of the optical density of VEGF positive reaction of different groups indicated non significant decrease in VEGF optical density in indomethacin group. On the other hand autohealing group showed significant increase in comparison with indomethacin group. Prevented and treated groups showed a significant increase in comparison to indomethacin group (Table $3 \&$ Histogram 3 ). 

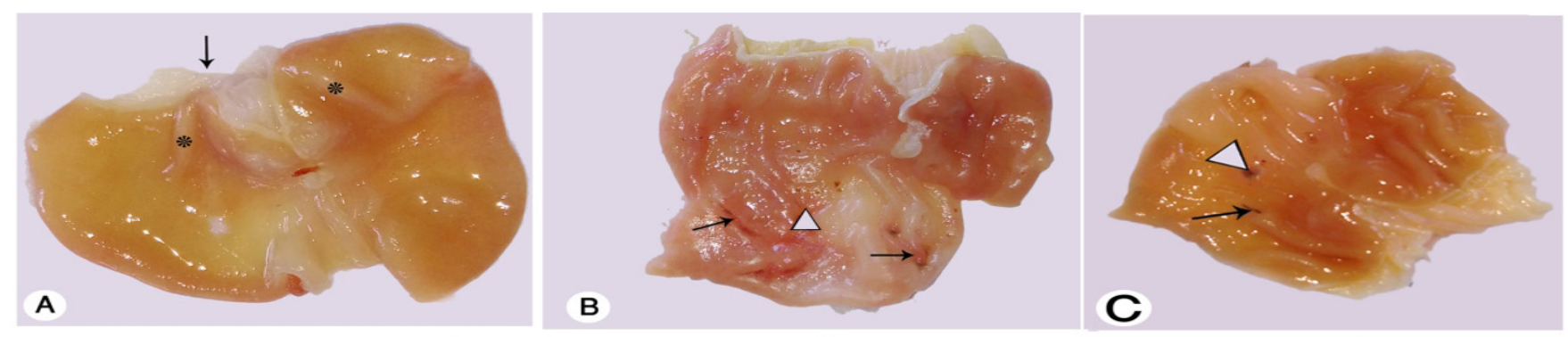

Fig. 1
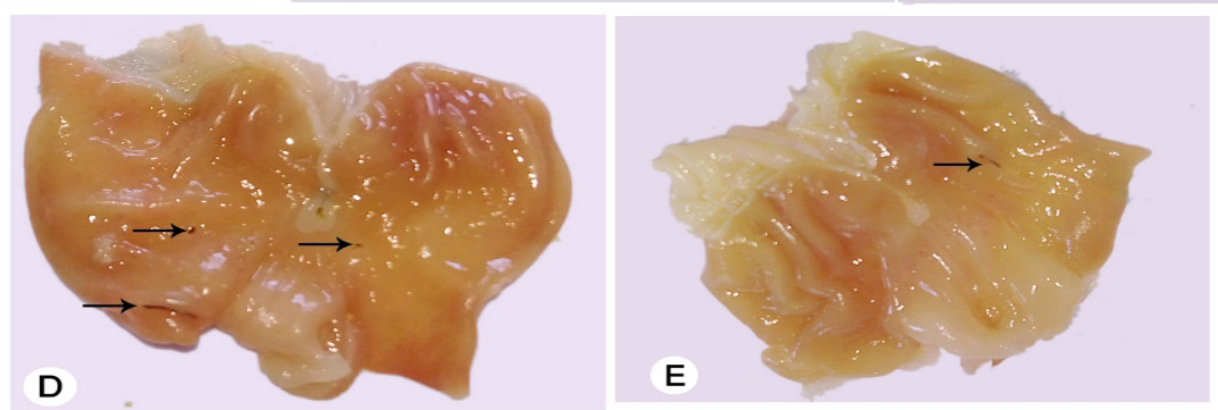

Fig.1: (A): Gross examination of the gastric mucosa of group (I) showing normal glandular part with prominent rugae $\left(^{*}\right)$ and white non glandular part near the esophageal end $(\uparrow)$. (B): group (III) showing hyperaemic mucosa with mucosal lesions of different sizes and colors $(\Delta)$ and hemorrhagic streaks $(\uparrow)$. $(\mathrm{C})$ : group (IV) showing hyperaemia, hemorrhagic streak $(\uparrow)$ and macroscopic mucosal lesions of different sizes and shapes ( $\Delta$ ). (D): group (V) showing mild hyperaemic mucosa with apparent few dark brown lesions $(\uparrow)$. (E): group (VI) showing apparently normal pinkish mucosa with prominent rugae $(*)$ and a small brownish lesion $(\uparrow)$.
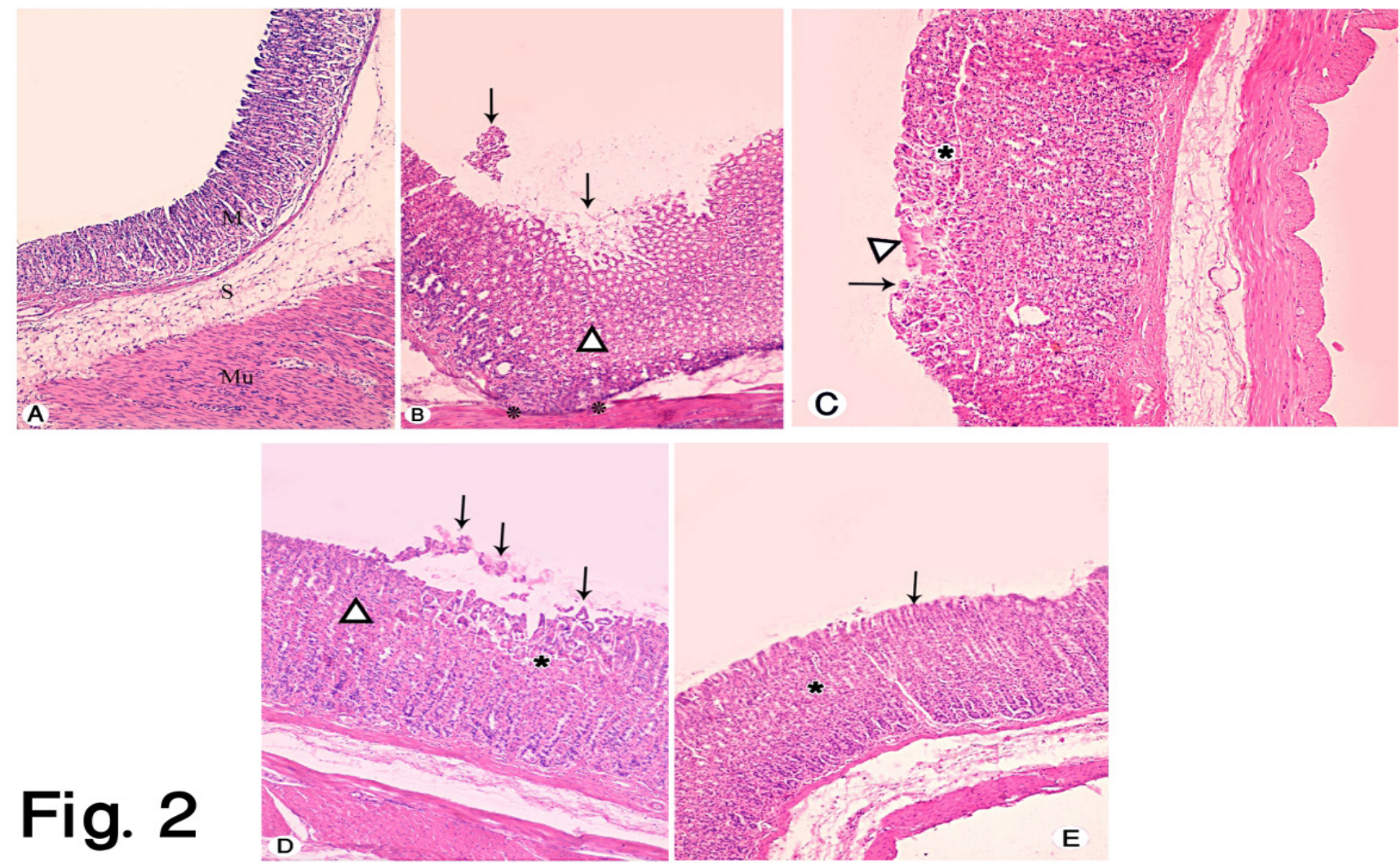

Fig. 2: (A): group (I) showing normal mucosa (M), submucosa (S) and muscularis externa (Mu). (B): group (III) showing desquamated surface epithelial cells in the lumen $(\uparrow)$ and Loss of normal glandular architecture $(\Delta)$. Thickening of lower part of mucosa with extension into muscularis externa $(*)$ is noticed. $(C)$ : group (IV) showing focal mucosal damage. Some surface epithelial cells are desquamated and shrinked with deeply stained cytoplasm and pyknotic nuclei $(\uparrow)$. The gastric glands have irregular cellular arrangment $(*)$. Granulation tissue appears in the lesion area ( $\Delta$ ). (D): group (V) showing mild desquamation of surface epithelial cells with some shedded cells in the lumen $(\uparrow)$. There is mild loss of normal glandular architecture at site of lesion $(\Delta)$ with preservation of normal architecture in other areas $(*)$. (E): group (VI) showing apparently normal mucosa $(\uparrow)$ with maintained normal glandular architecture $(*)$. (H\&E x 100) 


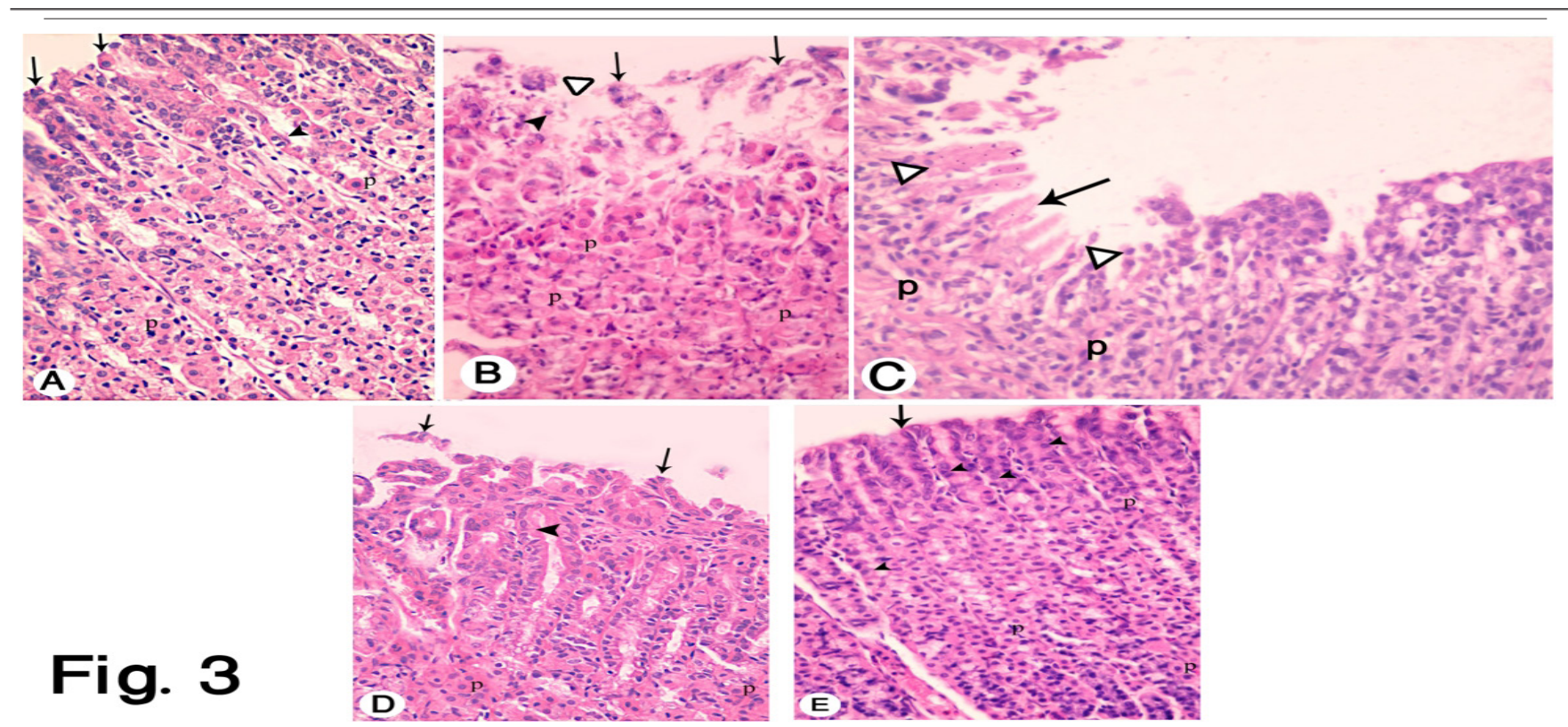

Fig.3: (A) : group (I) showing the mucosa with surface epithelial cells $(\uparrow)$ and normal glandular architecture. The surface epithelial cells are columnar acidophilic cells with oval basal vesicular nuclei. The gastric pits are short, narrow and lined by columnar surface mucous cells. Gastric glands show mucous neck cells and parietal cells. Mucous neck cells (४) have basal vesicular nuclei and pale acidophilic foamy cytoplasm. Parietal cells (p) are polyhedral with rounded vesicular nuclei and deep acidophilic cytoplasm. (B): group (III) showing desquamated shrinked cells with deep acidophilic cytoplasm and pyknotic nuclei $(\uparrow)$.Gastric pits are wide $(\Delta)$. Mucous neck cells $(\varangle)$ and parietal cells (P) have vacuolated cytoplasm and pyknotic nuclei. (C): group (IV) showing mucous neck cells $(\Delta)$ and parietal cells $(\mathrm{P})$ with vacuolated cytoplasm and pyknotic nuclei. Granulation tissue appears in the lesion area $(\uparrow)$. (D): group $(\mathrm{V})$ showing preservation of surface epithelial cells $(\uparrow)$, but some cells are shrinked and shedded with deep acidophilic cytoplasm and basal dense nuclei $(\Delta)$.Few mucous neck cells ( ) and parietal cells (p) appear with vacuolated cytoplasm and vesicular nuclei. (E): group (VI) showing normal superficial epithelial cells $(\uparrow)$ with basal oval nuclei and pale acidophilic cytoplasm. Mucous neck cells ( $)$ have flat basal nuclei and pale foamy cytoplasm. Parietal cells (P) have rounded vesicular nuclei and deep acidophilic cytoplasm with mild vacuolation. (H\&E x400)

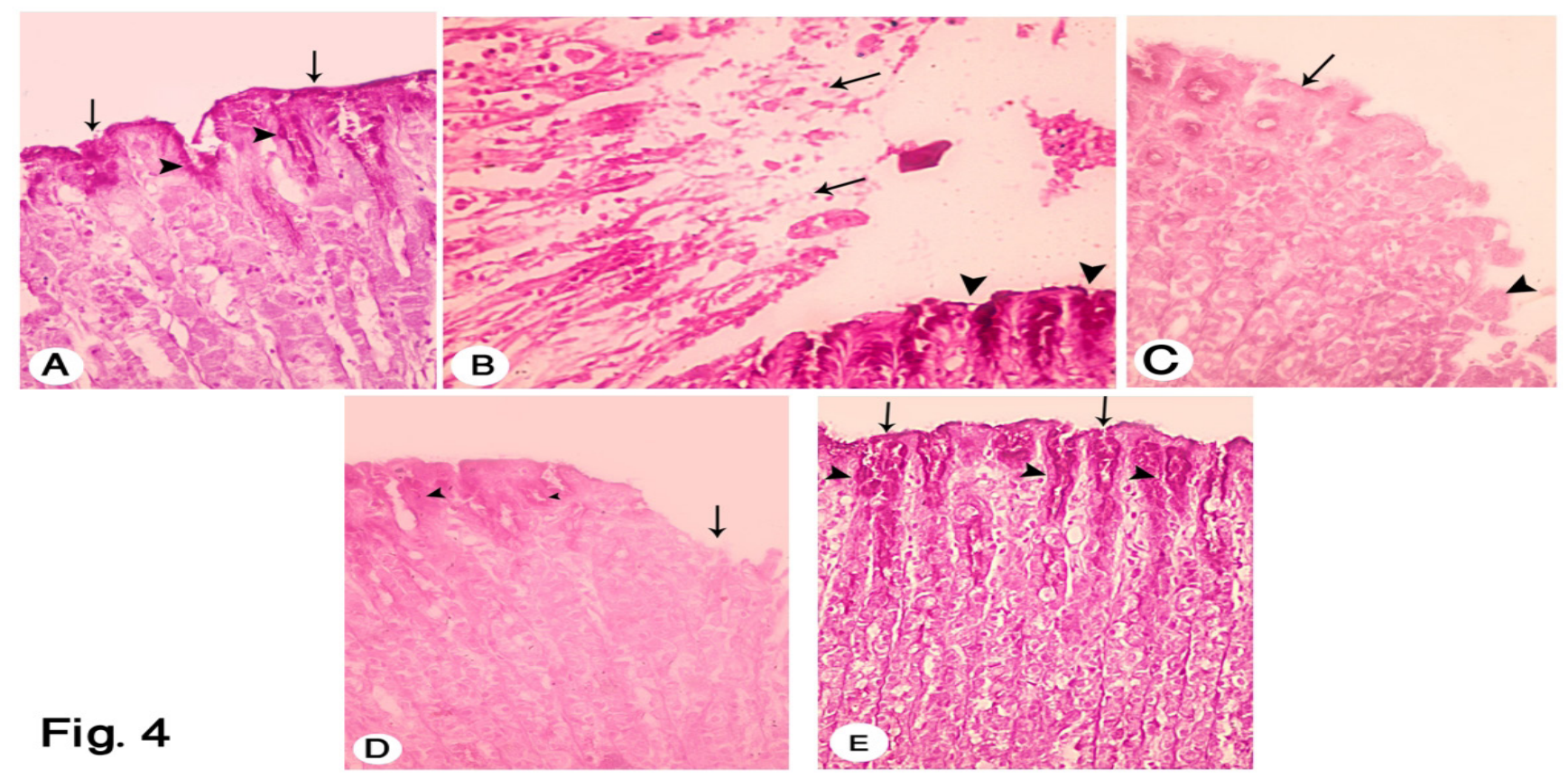

Fig.4 (A) : group (I) showing PAS positive thick continuous mucous film over the surface epithelium ( $\uparrow$ ) .It extends to the gastric pits ( 4$)$. (B): group (III) showing loss of PAS reaction over surface epithelium $(\uparrow)$ with positive thin PAS reaction in the normal epithelium next to the injured one ( $<$ ). (C): group (IV) showing showed faint thin PAS positive reaction of surface mucous film in some areas $(\uparrow)$. Other damaged areas showed loss of PAS reaction over surface epithelium (४). (D): group (V) showing moderate positive PAS reaction of surface mucous film in some areas ( $\uparrow$ ) with loss of PAS reaction over surface epithelium in other areas (४). (E): group (VI) showing continuous slightly thick positive PAS reaction of surface mucous film $(\uparrow)$ which extends to gastric pits (4). (PAS x 400) 

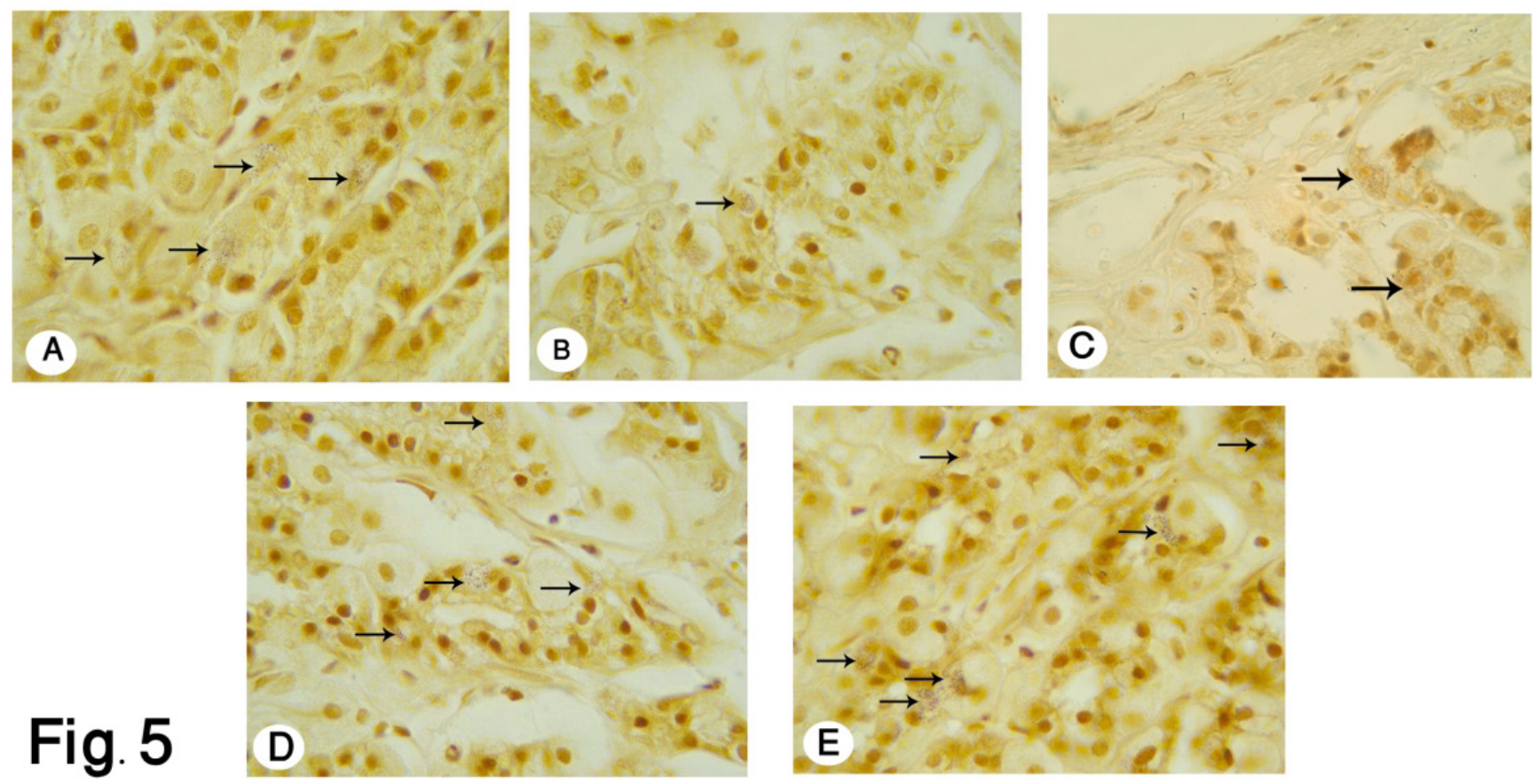

Fig. 5 (A): group (I) showing enteroendocrine cells with dense brown secretory granules ( $\uparrow$ ). (B): group (III) showing an enteroendocrine cell with hardly seen brown secretory granules $(\uparrow)$. (C): group (IV) showing few amount of the enteroendocrine cells with faint brown secretory granules. (D): group (V) showing apparently few enteroendocrine cells with dense brown secretory granules $(\uparrow)$. (E): group (VI) showing apparently numerous enteroendocrine cells with dense brown secretory granules $(\uparrow)$. (Double silver impregnation modification of Pascual x1000)

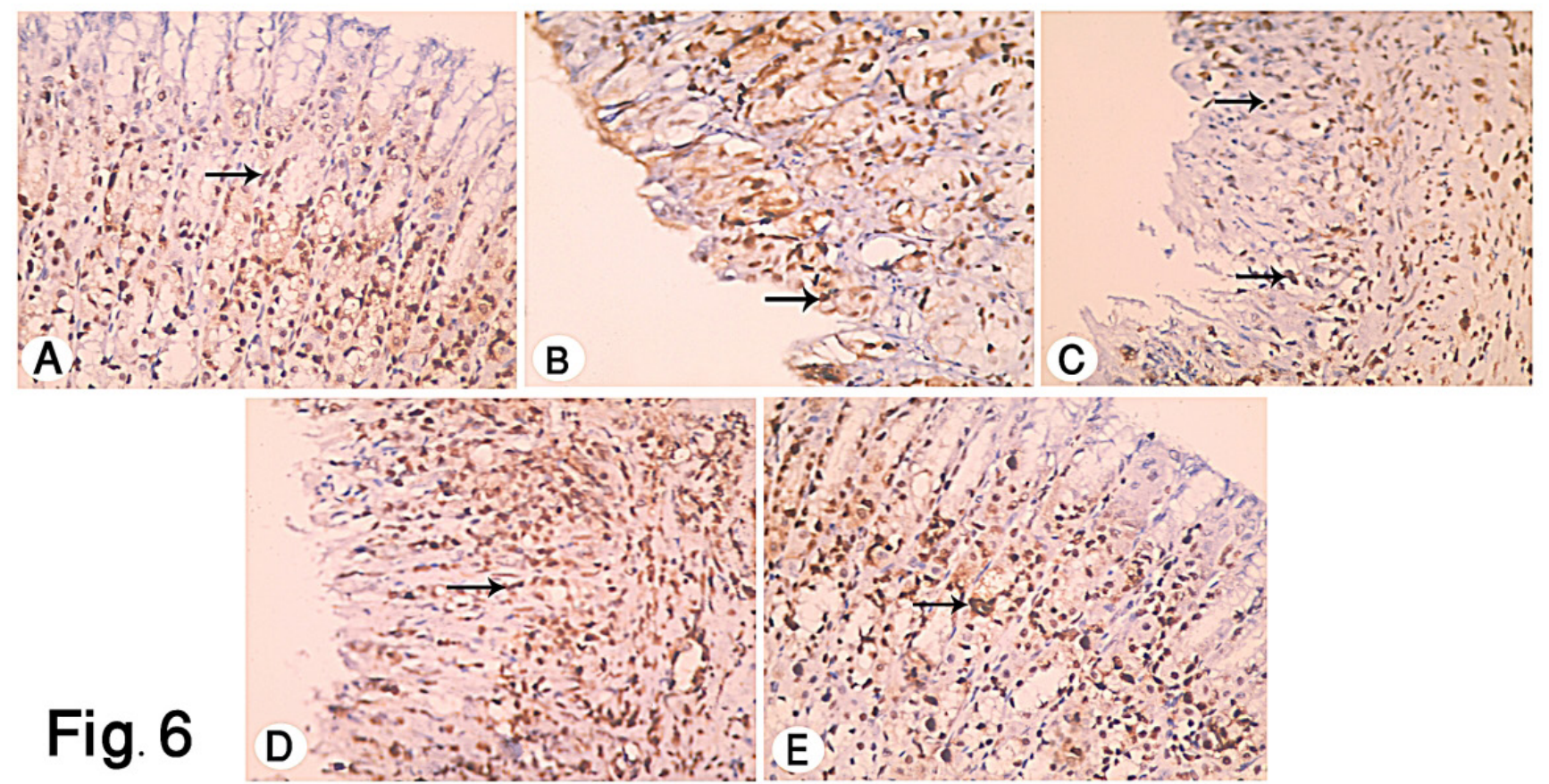

Fig. 6 (A): group (I) showing PCNA positive nuclei in the cells of the fundic glands ( $\uparrow$ ). (B): group (III) showing few scattered PCNA-positive cells ( $\uparrow)$. (C): group (IV) showing some PCNA-positive cells $(\uparrow)$. (D): group (V) showing moderate amount of PCNA-positive cells ( $\uparrow$ ). (E): group (VI) showing numerous PCNA-positive cells $(\uparrow) . \quad$ (PCNA immunostaining x 400). 


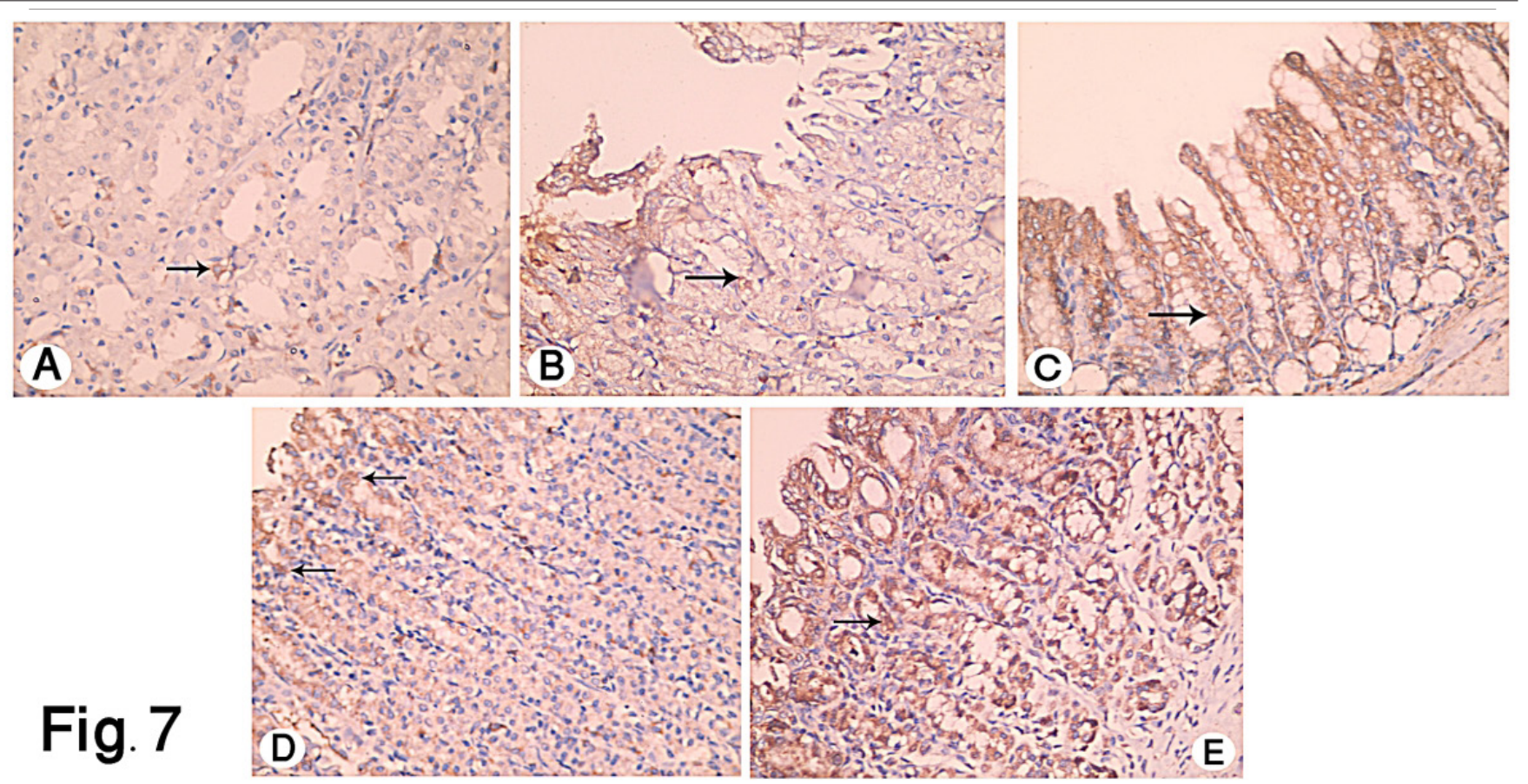

Fig.7 (A): group (I) showing positive VEGF reaction localized in the cytoplasm of endothelium of blood vessels ( $\uparrow$ ).(B): group (III) showing faint VEGF positive reaction ( $\uparrow$ ). (C): group (IV) showing mild VEGF positive reaction ( $\uparrow$ ). (D): group (V) showing moderate VEGF positive reaction ( $\uparrow$ ). (E): group (VI) showing strong VEGF positive reaction ( $\uparrow$ ). (VEGF immunostaining $\mathrm{x} 400)$.
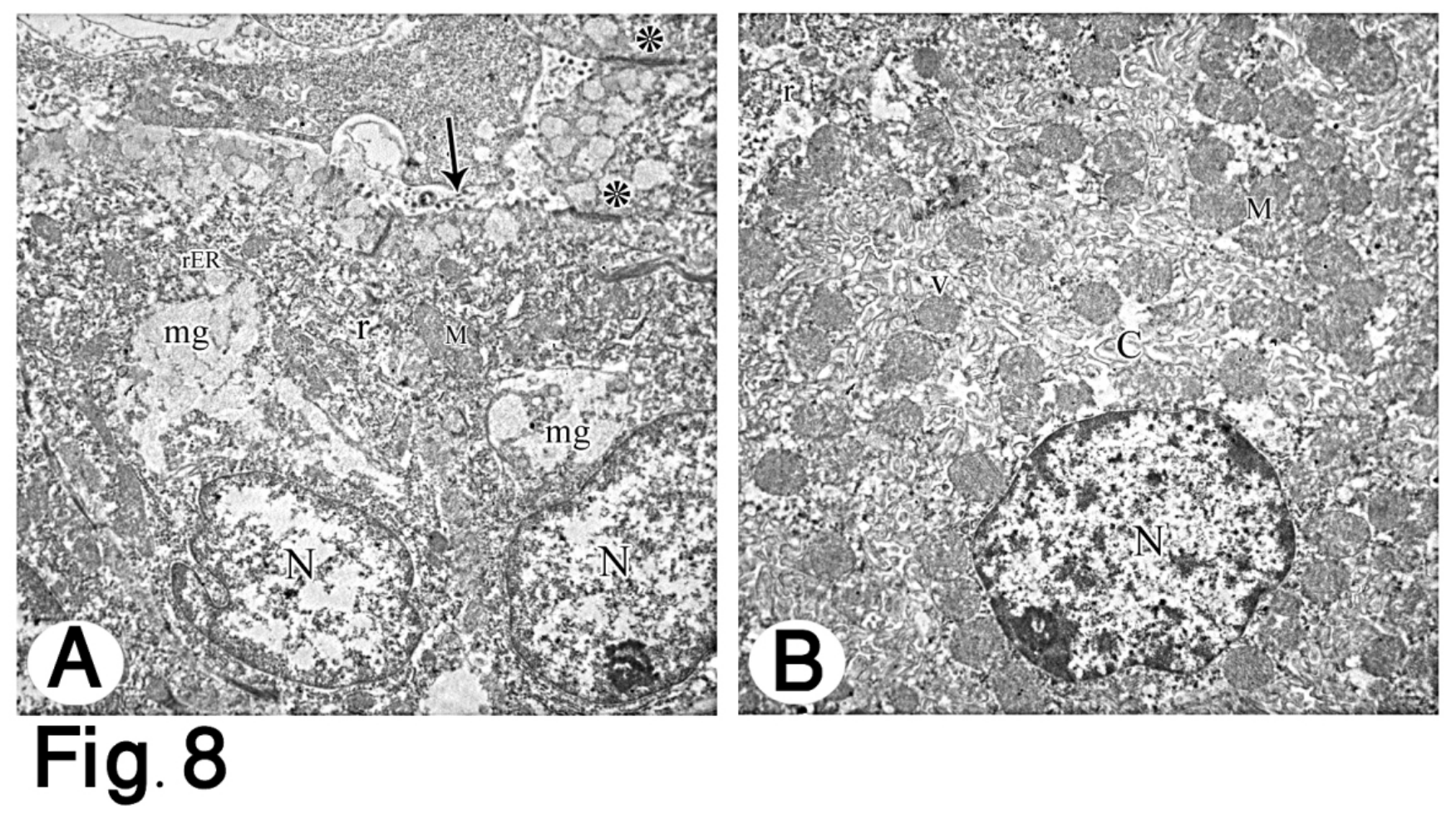

Fig. 8 (A): group (I) showing mucous secreting cell with an euchromatic nucleus (N) with prominent nucleolus and regular nuclear membrane. The apical cytoplasm is filled with different sized mucous secretory granules with moderate electron density (mg). Numerous ribosomes (r), rough endoplasmic reticulum $(\mathrm{rER})$ and mitochondria with regular cristae $(\mathrm{M})$ are noticed. Notice, microvilli $(\uparrow)$ and tight junctions with the neighbouring cells $\left({ }^{*}\right)$. ( TEM $\times$ 5800). (B): showing parietal cell with an euchromatic nucleus(N) with regular distribution of chromatin , prominent nucleoli and regular nuclear membrane. Numerous mitochondria (M) with intact regular cristae and ribosomes are observed (r). Notice, intracellular canaliculi (C) and well-developed tubulovesicles (V). ( TEM $\times 5800)$ 

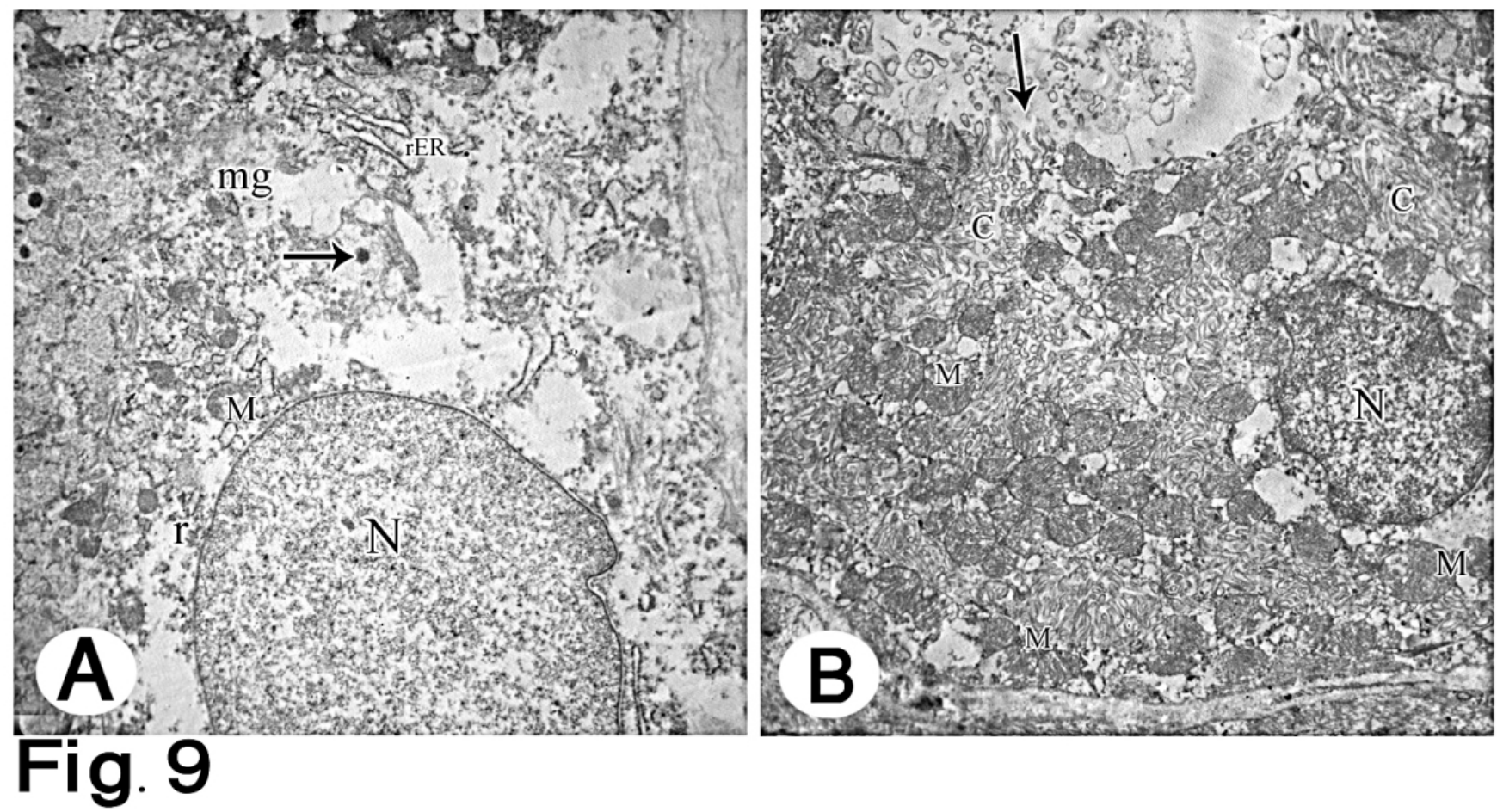

Fig. 9 (A): group (III) showing damaged mucous cell in with irregular nuclear membrane (N) . Cytoplasm is markedly rarified and and vacuolated with dense bodies $(\uparrow)$. Marked decrease in number and disruption of apical secretory mucous granules (mg). Few small dense mitochondria (M), few dilated rough endoplasmic reticulum (rER) and Few ribosomes (r) are noticed. （ TEM x7200). (B): showing parietal cell with vacuolated cytoplasm ( $\uparrow$ ), irregular small nucleus $(\mathrm{N})$ with dense clumps of heterochromatin. Some mitochondria (M) are destroyed with irregular cristae and different sizes. Dilated intracellular canaliculi (C) with luminal debris $(\Delta)$. ( TEM x 5800)
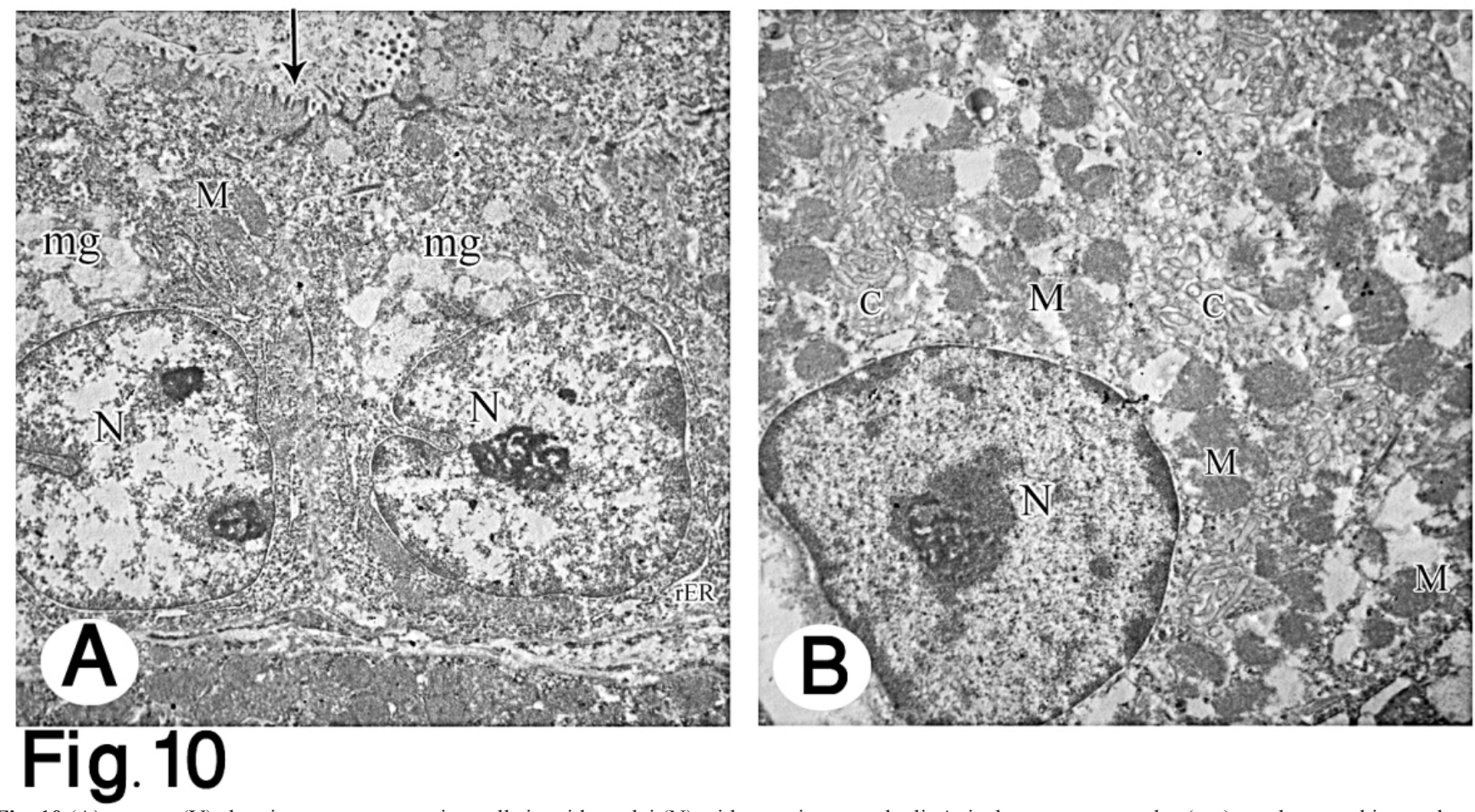

Fig. $10(A)$ : group $(V)$ showing mucous secreting cells in with nuclei $(\mathrm{N})$ with prominent nucleoli. Apical secretory granules (mg) are decreased in number Some mitochondria (M) are irregular. Rough endoplasmic reticulum (rER), ribosomes and microvilli ( $\uparrow$ ) are noticed. (TEM x7200) (B): showing parietal cell with an euchromatic nucleus $(\mathrm{N})$, prominent nucleolus and dense clumps of heterochromatin.Cytoplasm is vacuolated. Some mitochondria (M) are disrupted, variable in size with irregular cristae. Dilated intracellular canaliculi (C) are seen . (TEM x 7200) 

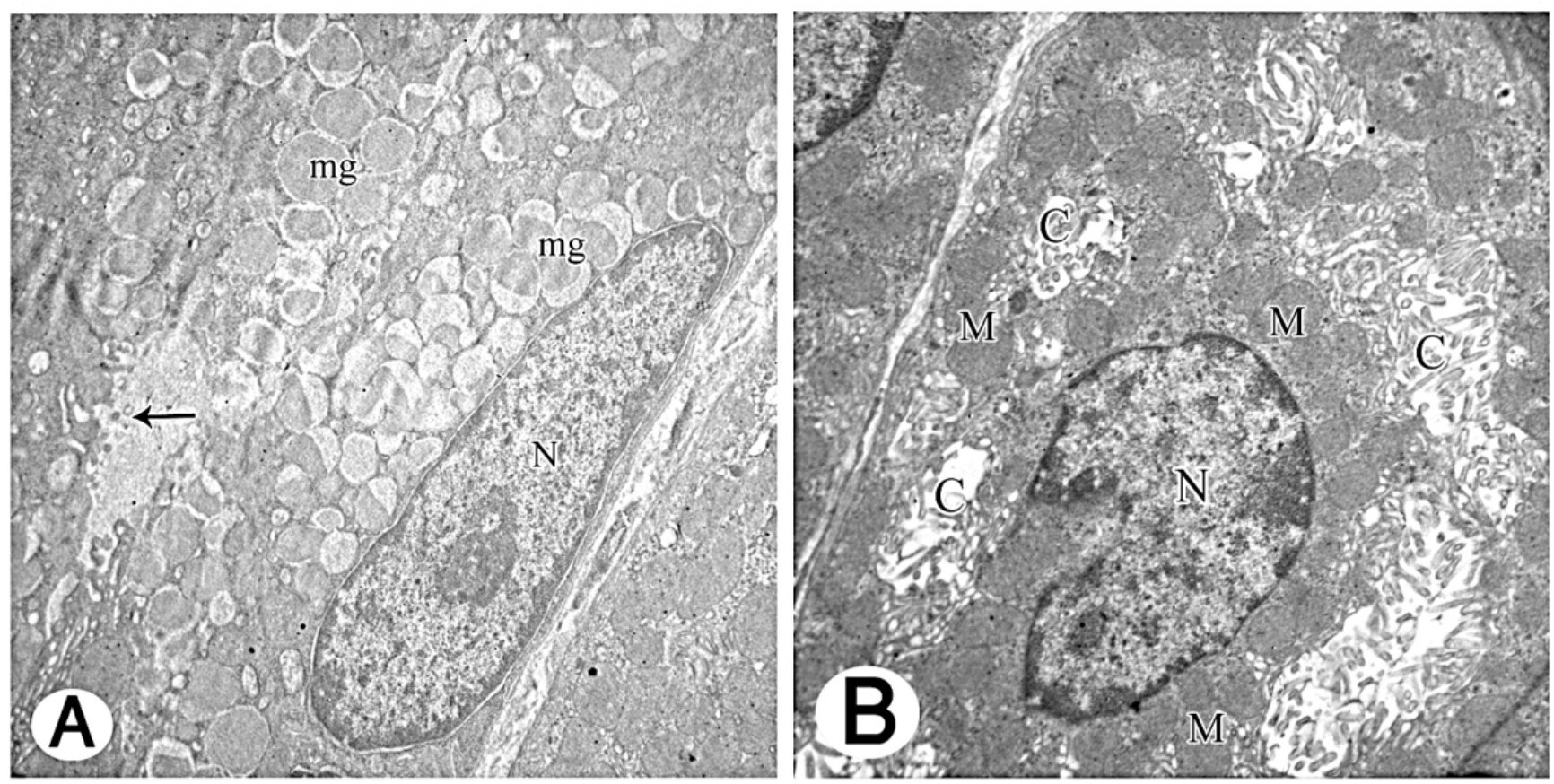

Fig.11

Fig.11 (A): group (VI) showing mucous secreting cell with oval nucleus (N), regular distribution of heterochromatin ,prominent nucleolus and regular nuclear membrane. microvilli $(\uparrow)$ and numerous mucous secreting granules (mg) with different sizes and electron densities are noticed. (TEM x7200) (B): showing parietal cell with an euchromatic nucleus , regular nuclear membrane and dense regular heterochromatin $(\mathrm{N})$. Numerous mitochondria $(\mathrm{M})$ with regular cristae are noticed. Notice, mild dilated intracellular canaliculi (C). ( TEM x 7200 )

Table (1): Showing the mean number of Enter endocrine cells

\begin{tabular}{|c|c|c|c|c|c|}
\hline No. of cells & Control & Ulcer & Auto-healing & Prevented & Treated \\
\hline Mean \pm SD & $6.92 \pm 4.12$ & $2.09 \pm 2.59$ & $3.15 \pm 1.57$ & $4.44 \pm 4.96$ & $6.34 \pm 4.32$ \\
\hline Median (Range) & $7.0(0.0-20.0)$ & $1.0(0.0-10.0)$ & $3.0(1.0-6.0)$ & $3.0(0.0-18.0)$ & $6.0(0.0-18.0)$ \\
\hline P-value ${ }^{1}$ & & $0.000^{*}$ & $0.001^{*}$ & $0.000^{*}$ & 0.350 \\
\hline $\mathrm{P}$ - value $\mathrm{e}^{2}$ & & & $0.017^{*}$ & $0.002^{*}$ & $0.000^{*}$ \\
\hline $\mathrm{P}$ - value ${ }^{3}$ & & & & $0.026^{*}$ & $0.007^{*}$ \\
\hline P-value ${ }^{4}$ & & & & & $0.000^{*}$ \\
\hline
\end{tabular}

1: Comparison with Control

2: Comparison with Ulcer

3: Comparison with Auto-healing 4: Comparison with Prevented

* Statistical significant difference $(\mathrm{p}<0.05)$

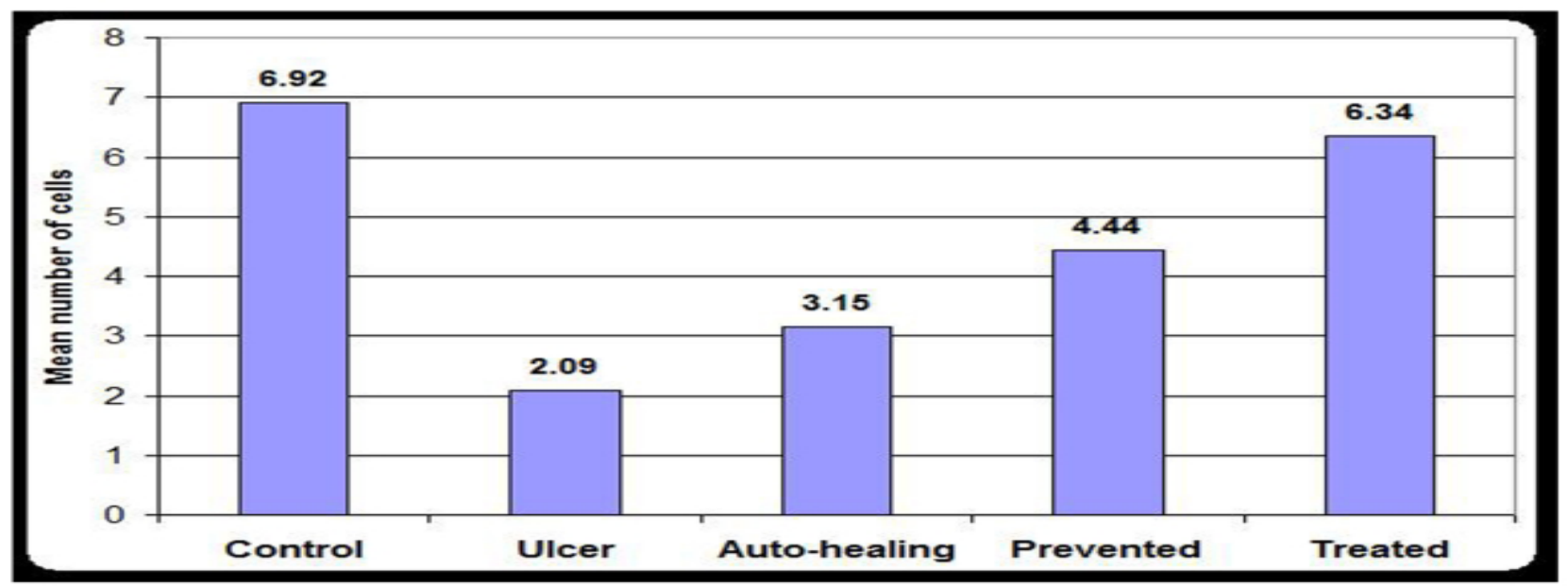

Histogram (1): The mean number of Enteroendocrine cells 
Table (2): Showing the mean number of PCNA positive cells

\begin{tabular}{|c|c|c|c|c|c|}
\hline No. of cells & Control & Ulcer & Auto-healing & Prevented & Treated \\
\hline Mean \pm SD & $96.9 \pm 12.68$ & $95.78 \pm 28.69$ & $105.20 \pm 12.37$ & $131.33 \pm 34.30$ & $144.56 \pm 6.56$ \\
\hline Range & $80.0-113.0$ & $70.0-153.0$ & $85.0-122.0$ & $72.0-175.0$ & $124.0-175.0$ \\
\hline P-value ${ }^{1}$ & & 0.368 & 0.187 & $0.039^{*}$ & $0.001^{*}$ \\
\hline P-value ${ }^{2}$ & & & 0.121 & $0.042^{*}$ & $0.005^{*}$ \\
\hline P-value ${ }^{3}$ & & & & $0.045^{*}$ & $0.000^{*}$ \\
\hline P-value ${ }^{4}$ & & & & & 0.536 \\
\hline
\end{tabular}

1: Comparison with Control

2: Comparison with Ulcer

3: Comparison with Auto-healing

4: Comparison with Prevented

* Statistical significant difference $(\mathrm{p}<0.05)$

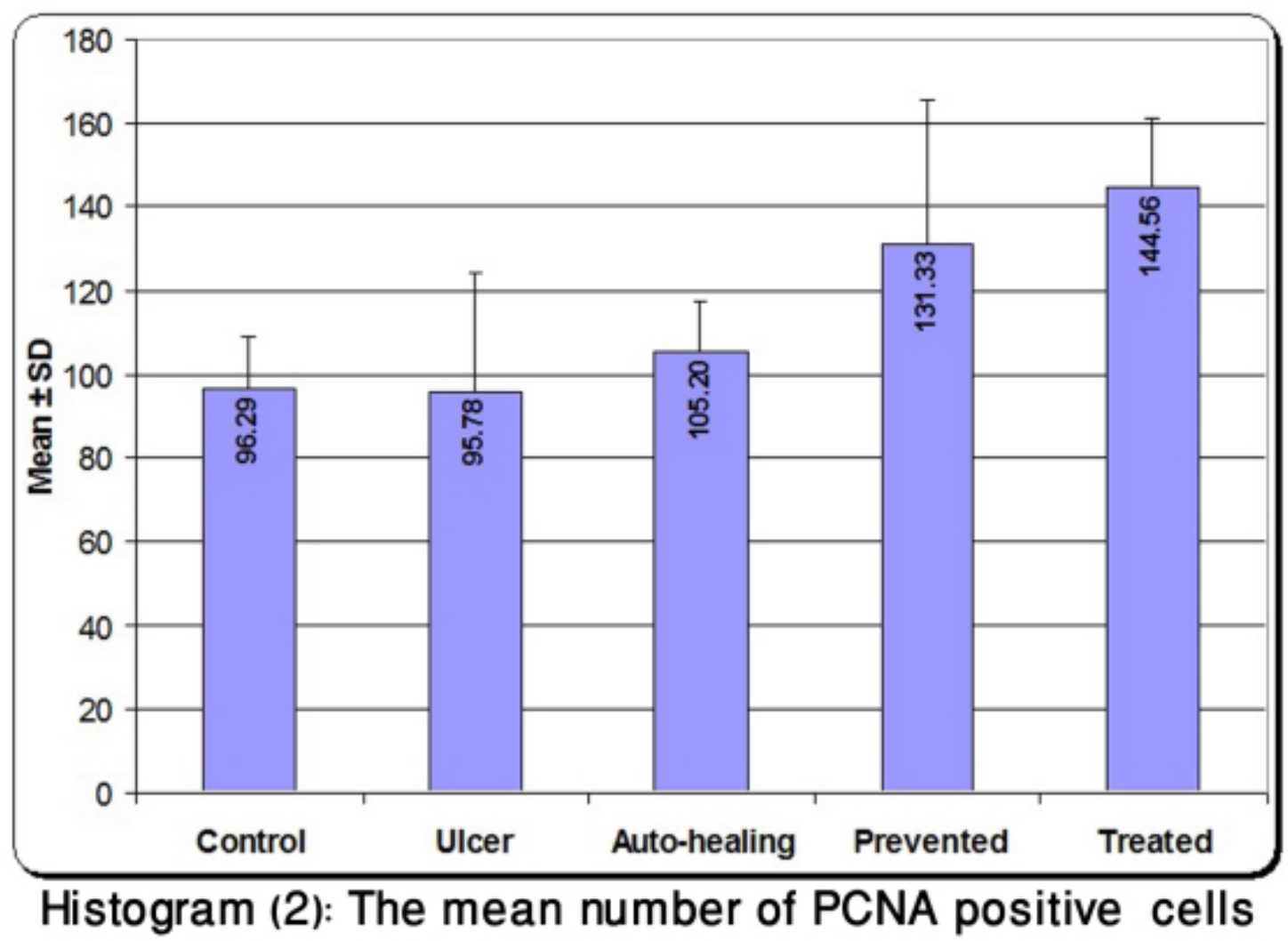


Table (3): Showing the mean optical density of VEGF reaction

\begin{tabular}{|c|c|c|c|c|c|}
\hline VEGF & Control & Ulcer & Auto-healing & Prevented & Treated \\
\hline Mean \pm SD & $0.272 \pm 0.006$ & $0.280 \pm 0.013$ & $0.307 \pm 0.016$ & $0.321 \pm 0.022$ & $0.417 \pm 0.041$ \\
\hline Range & $0.266 \pm 0.279$ & $0.265 \pm 0.293$ & $0.285 \pm 0.322$ & $0.302 \pm 0.325$ & $0.346 \pm 0.457$ \\
\hline P-value ${ }^{1}$ & & 0.480 & $0.017^{*}$ & $0.025^{*}$ & $0.020^{*}$ \\
\hline P- value ${ }^{2}$ & & & $0.038^{*}$ & $0.014^{*}$ & $0.011^{*}$ \\
\hline P- value ${ }^{3}$ & & & & 0.372 & $0.003^{*}$ \\
\hline P- value ${ }^{4}$ & & & & & $0.011^{*}$ \\
\hline
\end{tabular}

1: Comparison with Control

2: Comparison with Ulcer

3: Comparison with Auto-healing

4: Comparison with Prevented

* Statistical significant difference $(\mathrm{p}<0.05)$

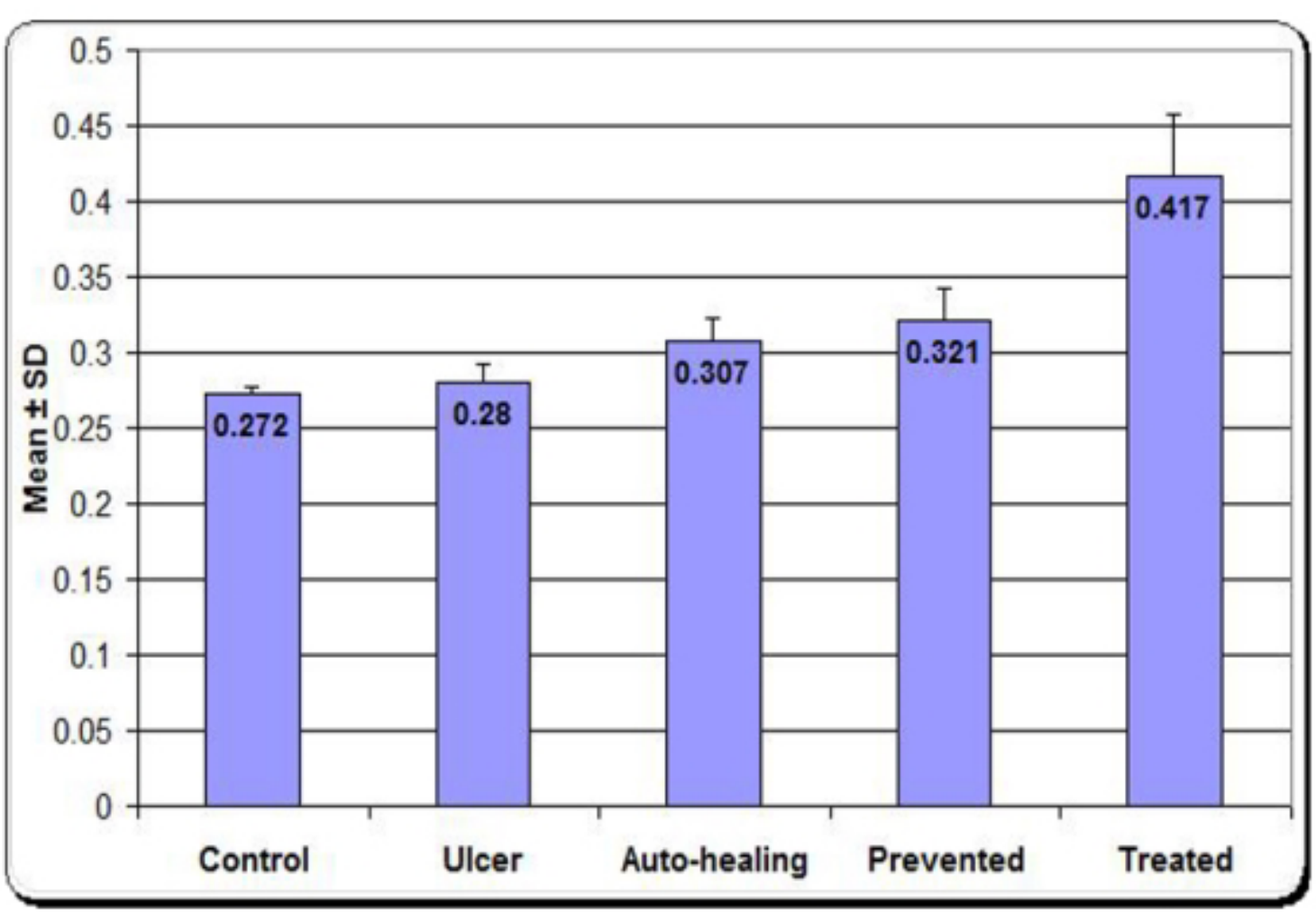

Histogram (3): The mean optical density of VEGF reaction 


\section{DISCUSSION}

Indomethacin has a higher potentiality to cause gastric injury than other NSAIDs. It is also known to increase gastric aggressive factors and decrease the defensive factors ${ }^{(11)}$. In the present work, indomethacin group showed hyperaemic mucosal lesions with hemorrhagic streaks, shedding of surface epithelial cells and loss of normal glandular architecture. This was in agreement with previous study ${ }^{(12)}$ that reported that the erosions might be due to the direct effect of indomethacin on epithelial cells that results in cell death and epithelial exfoliation.

Indomethacin group also showed disruption of mucous secreting cells and loss of PAS reaction in damaged areas. This was explained by previous study ${ }^{(13)}$ that reported that indomethacin induced defect in gastric mucosal barrier leading to back diffusion of acid and reduced mucosal resistance which results in damage to gastric mucosa. NSAIDs cause generation of oxygen free radicals through damage of mucosal barrier and tissue acidosis. This leads to coupling of oxidative phosphorylation in mitochondria resulting in releasing oxygen free radicals ${ }^{(14)}$.

In our study, indomethacin group showed destroyed mitochondria with irregular cristae. This was in agreement with previous study ${ }^{(15)}$ that explained that mitochondrial damage might be due to inhibition of electron transport and /or uncoupling of oxidative phosphorylation. Uncoupling of oxidative phosphorylation decreased cellular ATP production and cellular calcium toxicity. It also affected the mitochondrial membrane potential and liberation of reactive oxygen species leading to cellular lipid peroxidation and cellular apoptosis. This effect might be the biochemical mechanism of indomethacin toxicity as mitochondria are considered the intracellular organelle target of NSAIDs ${ }^{(16)}$.

In the present work indomethacin caused widening of the intercellular spaces. This indicates loss of integrity of the intercellular junctions. Tight junctions between surface epithelial cells form a barrier preventing diffusion of acid and pepsin. They also prevent back diffusion of aggressive factors which cause gastric irritation like aspirin ${ }^{(17)}$. This was confirmed by previous study ${ }^{(18)}$ that reported that NSAIDs cause inhibition of oxidative phosphorylation which leads to intracellular ATP deficiency and leakage of calcium ions $(\mathrm{Ca}+2)$ from mitochondria. These events lead to loss of integrity of intercellular junctions and increased permeability which allows access of aggressive factors to the mucosa leading to inflammation, bacterial invasion and ulcerations ${ }^{(18)}$.

Enteroendocrine cells release 5-Hydroxytryptamine (5-HT) which is an important autocrine hormone and neurotransmitter in the enteric plexus of the gut. It stimulates prostaglandins (PGs) synthesis which stimulates mucosal blood flow and helps in the secretion of mucous with bicarbonate ${ }^{(19)}$. In the present work indomethacin disrupted the enteroendocrine cells and significantly decreased their number and their secretory granules compared to the control group. This was in agreement with previous study ${ }^{(20)}$ that added that indomethacin induced inhibition of production of 5- HT from enteroendocrine cells through inhibition of PGE2. PGs biosynthesis is catalyzed by the enzyme cyclooxygenase (COX), which exists in two forms COX1 and COX-2. COX-1 derived PGs are known to regulate gastric $\mathrm{pH}$, while $\mathrm{COX}-2$ derived $\mathrm{PGs}$ have the ability to increase proliferation of epithelial cells and regeneration of the glands during repair. Inhibition of both COX-1 and COX-2 induces mucosal damage, as both enzymes are essential factors in mucosal defensive mechanisms ${ }^{(21)}$.

Regarding the parietal cell, indomethacin group showed dilated intracellular canaliculi, vacuolated cytoplasm and destroyed mitochondria. Dilatation of the canaliculi and pits after indomethacin administration indicates hypersecretion of the glands. This was explained by previous study ${ }^{(22)}$ that reported that hypersecretion of the gastric glands could be related to PGI2 and PGE2 inhibition by NSAIDs, as they are potent anti-secretory agents.

In this work, we used dried unrippen banana powder as banana lose their activity on ripening. The active factors of banana are thermolabile and water soluble ${ }^{(23)}$. In banana only group, the gross appearance of the stomach was similar to the control group which indicates that banana apparently has no harmful effect on normal stomach. This was confirmed by previous study (3) that supported the safety of banana extracts. Moreover, banana was found to stimulate cellular proliferation and increases mucosal thickness ${ }^{(5)}$.

In prevented group, the gastric mucosa showed mild hyperaemia and apparent less lesions compared to indomethacin only group. Also there was moderate PAS positive reaction of surface mucous film in some areas and the mucous secreting cells showed less damage compared to indomethacin group. This was in agreement with previous study ${ }^{(23)}$ that reported that banana has the ability to stimulate growth of gastric mucosa with increased mucous production. So the regenerated mucosal cells could seal the damaged areas with a secretory layer of mucous and inducing rapid re-epithelization of the ulcerated gastric mucosa and preventing further damage. This was also confirmed with previous study ${ }^{(24)}$ that claimed that banana have the ability to protect basic fibroblast growth factors which is responsible for epithelial regeneration in acidinduced ulcers. Ethanolic extracts in banana was reported to increase eicosanoids like prostaglandins $\mathrm{E}$ and $\mathrm{I} 2$ and leukotrienes in the human gastric and colonic mucosa. PGs are considered one of the factors that prevent ulcer as they increase mucous secretion ${ }^{(14)}$.

Reactive oxygen species (ROS) are normally neutralized by the action of antioxidant system including glutathione peroxidase, catalase (CAT), superoxide dismutase (SOD) and others ${ }^{(25)}$. If there is imbalance between ROS and antioxidant, deregulation of cellular functions occurs. This leads to membrane lipids peroxidation, lipid peroxides accumulation and cellular 
damage $^{(26)}$. Flavonoids which present in unripen banana are known to have antioxidant activity and scavenge oxygn free radicals thus prevent DNA damage and decrease lipid peroxidation. They may protect mucosa by stimulation of cellular proliferation, repithelialization and increasing the mucous secretion ${ }^{(27)}$. So banana has protective action on the cell and may also increase mucosal resistant to harmful effects of the drugs ${ }^{(5)}$. This was in agreement with previous study ${ }^{(23)}$ that reported that banana has activity in inhibiting the formation of ulcers by aspirin. They explained its mechanism of action by stimulating the growth of gastric mucosa and increasing the production of mucus which was responsible for its protective effect. As the regenerated mucosa cells could cover damaged areas with a secretory layer of mucus and prevent further lesions due to acid. Moreover, previous study ${ }^{(5)}$ reported that three months continuous treatment with dried banana powder caused decrease or delay in the relapse of peptic ulcer to 612- months. In contrary with these results, previous study ${ }^{(3)}$ have reported that aqueous extract of musa paradisiaca (banana family) did not have any protection against indomethacin induced gastric ulcer, although it had antiulcerogenic effect against aspirin. They suggested that synergistic combination happened between indomethacin and any of the phytochemicals present in the extract.

In treated group, we found that the gastric mucosa was more or less similar to control group with only one small mucosal lesion. This was explained by previous study ${ }^{(28)}$ that found that Musa sapientum caused dosedependant faster healing and increased tesnile strength of the healed incision wounds. This was in agreement with previous study ${ }^{(29)}$ that found that about $40-70 \%$ of endoscopically diagnosed duodenal ulcers healed after 12 weeks of treatment with dried banana powder as compared to about $16 \%$ with placebo. We also observed strong positive PAS reaction in treated group which might be an indication of increased mucous secretion by banana. This was explained by previous study ${ }^{(30)}$ that reported that for the healing process, the mucus thickness should be maintained or even increased to protect the regenerating mucosa as mucus strengthens the mucosal barrier. This was in agreement with previous study ${ }^{(31)}$ that reported that banana-caused thick mucus barrier protects newly formed cells from acid $\mathrm{pH}$ and proteolytic effect of gastric secretions. Moreover, mucous could act as antioxidant and thus reduces mucosal damage mediated by ROS. So, banana would enhance rapid gastric ulcer healing by increasing synthesis and secretion of gastric mucous ${ }^{(26)}$.

In our study, parietal cells in prevented and treated groups showed some damage but to a lesser extent than in ulcer group. This was in agreement with previous studies $^{(3,27)}$ that reported that Musa sapientum extract caused significant decrease in the total gastric acidity in pyloric ligation induced ulceration. This effect is consistent with the ability of flavonoid in inhibiting HCL secretion $^{(26)}$.
Furthermore in prevented and treated groups the enteroendocrine cell number was increased. This was in agreement with previous $\operatorname{study}^{(32)}$ that reported that banana contains high levels of 5-HT. In contrast, previous study ${ }^{(5)}$ have reported that the antiulcer effect of banana was not due to its 5-HT content but probably due to its predominant effect on mucosal defensive factors.

Cell proliferation plays a major role in the healing of gastric ulcers. The epithelial regeneration occurs by proliferation of undifferentiated epithelial cells, which migrate from the lesion border to cover the base of the ulcer. The balance between apoptosis and proliferation is important for the maintenance of epithelium as without a continuous epithelial barrier the mucosa would be exposed to infection and chemical injury leading to prevention of the ulcer healing ${ }^{(33)}$. PCNA is a nuclear peptide that is expressed during cell proliferation ${ }^{(34)}$. The present results showed that indomethacin showed a significant decrease in the number of mucosal PCNA positive cells. Also we observed that banana treated group presented significant increase in PCNA positive cells comparing to control, indicating greater cell proliferation in the regenerative mucosa. It might be suggested that banana effect on mucosal regeneration depends also on acid-independent mechanisms, which are likely related to its antioxidant properties. This was supported by previous study ${ }^{(35)}$ that reported that banana increased the expression of growth factors, including transforming growth factor-alpha, in the gastric mucosa of rats treated with aspirin.

Gastric blood flow provides gastric epithelial cell with bicarbonate which neutralize the acid and maintain neutral $\mathrm{pH}$ in mucous layer. It also helps mucosal renewal by providing oxygen and nutrients to gastric mucosa ${ }^{(36)}$. In the current study, to determine angiogenesis, VEGF expression was measured. VEGF is a vascular permeability factor and also a growth factor which induces angiogenesis that occurs during healing of injured tissues $^{(36)}$. We found that in indomethacin group, there was decreased VEGF positive reaction. This was in agreement with previous study ${ }^{(37)}$ that found that disruption of the vascular tissues of gastric mucosal endothelium lead to ulcer formation and increased vascular permeability. They ${ }^{(37)}$ have reported that VEGF expression has been stimulated by COX-2 through PGE2 in cultured gastric fibroblasts. They ${ }^{(37)}$ concluded that the inhibition of PGE2 biosynthesis by indomethacin, COX-2 inhibitors, could delay the healing of ulcers and decrease angiogenesis and VEGF expression. So, angiogenesis is essential for the healing of gastric lesion and the prevention of ulcer relapse. The new blood vessels provide nutrient supply to the tissue so it accelerates the healing of ulcers ${ }^{(38)}$. In the present work we found that banana treatment increased the expression of VEGF in the gastric ulcer margin, but in prevention group the VEGF expression increased to a lesser degree. This was explained by previous study ${ }^{(39)}$ that found that banana treatment increased the expression of VEGF in the lesion area. So, although indomethacin inhibits VEGF expression; banana was still able to prevent 
the effects of indomethacin on ulcer healing.

In autohealing group we found that after two days of indomethacin injury, granulation tissue started to appear in the injured mucosa but no complete healing was observed. Also there was faint PAS positive reaction. Few numbers of PCNA positive cells and mild VEGF expression in granulation tissue were found in the autohealing group compared to treated group. This was in agreement with previous study ${ }^{(40)}$ that reported that autohealing of the damaged gastric mucosa needs several weeks and involves the formation of granulation tissue, angiogenesis, and regeneration of the glandular structure. This was also confirmed by previous study ${ }^{(37)}$ that found that acute gastric ulcer left for 14 days for autohealing showed large hemorrhagic injury in the mucosa and glands.

\section{CONCLUSIONS}

According to the present study, we can conclude that banana is more effective in the treatment of indomethacininduced gastric damage compared to its preventive effect. It also provides a faster healing rate compared to the autohealing group. Banana might be able to promote mucous secretion through promoting mucous cell growth and/or direct stimulation of these cells to secret mucous. Its efficacy in the healing of gastric injury is based on its ability to activate the expression of VEGF and stimulate proliferative factor PCNA.

\section{REFERENCES}

1. Boligon AA, de Freitas RB, de Brum TF, Waczuk EP, Klimaczewski CV, de Ávila DS, Athayde ML, de Freitas Bauermann L. Antiulcerogenic activity of scutia buxifolia on gastric ulcers induced by ethanol in rats. Acta Pharmaceutica Sinica B 2014; 4: 358367 -

2. Chatterjee A, Bandyopadhyay SK. Herbal remedy: An alternate therapy of nonsteroidal antiinflammatory drug induced gastric ulcer healing. Ulcers 2014.

3. Ezekwesili CN, Ghasi S, Adindu CS, Mefoh NC. Evaluation of the anti-ulcer property of aqueous extract of unripe musa paradisiaca linn. Peel in wistar rats. African Journal of Pharmacy and Pharmacology 2014; 8(39): 10061011-.

4. Kumar KS, Bhowmik D. Traditional and medicinal uses of banana. Journal of Pharmacognosy and Phytochemistry 2012; 1(3): 51.

5. Tandel K, Shah B. Evaluation of gastric antiulcerogenic action of vegetable plantain banana (musa sapientum var. Paradisiaca) in aspirin plus pylorus ligated albino rats. International Journal of Pharmaceutical Sciences and Research 2012; 3: 4387.
6. Enye J, Chineke H, Onubeze D, Nweke I .Evaluation of the healing effects of aqueous extracts of musa paradisiaca (unripe plantain) and brassica oleracea (cabbage) on peptic ulcer. J. Dental Med. Sci 2013; 8: 4046-.

7. Araujo DA, Takayama C, de-Faria FM, Socca EA, Dunder RJ, Manzo LP, Luiz-Ferreira A, SouzaBrito AR. Gastroprotective effects of essential oil from protium heptaphyllum on experimental gastric ulcer models in rats. Revista Brasileira de Farmacognosia 2011; 21: 721729-.

8. Bancroft JD, LaytonC. Theory \& practice of histological techniques, 7th ed.: Churchill Livingstone of Elsevier, Philadelphia; 2013. 172- 214.

9. Hyat MA. Chemical fixation. In: Principles and techniques of electron microscopy: biological applications. 4th ed. Edinburg, UK: Cambridge University Press. 2000. 485-.

10. Emsley R, Dunn G, White IR. Mediation and moderation of treatment effects in randomized controlled trials of complex interventions. Stat. Methods Med Res. 2010; 19: 237270-.

11. Morsy MA, Fouad AA: Mechanisms of gastroprotective effect of eugenol in indomethacin-induced ulcer in rats. Phytotherapy Research 2008; 22: 13611366-.

12. Kolawole I A, Francis SO. Effects of a type $\mathrm{V}$ phosphodiesterase inhibitor (tadalafil) on indomethacin-induced gastric ulceration in rats. International Journal of Tropical Medicine 2012; 7: 111116-

13. Zaki SM, Mohamed EA. Effect of glucocorticoids on indomethacin-induced gastric ulcer in the adult male albino rat: histological, morphometric and electron microscopy study. Archives of medical science 2014; 10: 381.

14. El-Ashmawy NE, Khedr EG, El-Bahrawy HA, Selim HM. Nebivolol prevents indomethacininduced gastric ulcer in rats. Journal of Immunotoxicology 2016; 13: 580589-.

15. Brand MD, Affourtit C, Esteves TC, Green K, Lambert AJ, Miwa S, Pakay JL, Parker N. Mitochondrial superoxide: Production, biological effects, and activation of uncoupling proteins. Free Radical Biology and Medicine 2004; 37: 755767-.

16. Matsui H, Shimokawa O, Kaneko T, Nagano Y, Rai K, Hyodo I. The pathophysiology of nonsteroidal anti-inflammatory drug (nsaid)-induced mucosal injuries in stomach and small intestine. Journal of Clinical Biochemistry and Nutrition 2011; 48: 107111-. 
17. Elhumeed FA, Yousif WB. Light and electron microscopic studies on the effect of a contraceptive drug on the stomach of mouse, Pakistan journal of biological sciences: PJBS 2008; 11: 153163-.

18. Bjarnason I, Macpherson A, Hollander D. Intestinal permeability: An overview. Gastroenterology 1995; 108: 15661581-.

19. Morrow J, Roberts LJ. Lipid-derived autacoids: Eicosanoids and platelet-activating factor, Hardman JG, Limbird LE, Gilman AG-Goodman \& Gilman's The Pharmacological Basis of Therapeutics: New York, McGraw-Hill; 2001; 669685-.

20. Engelmann BE, Bindslev N, Poulsen SS, Hansen MB. Effects of cyclooxygenase and lipoxygenase inhibition on basal-and serotonininduced ion transport in rat colon, Comparative Biochemistry and Physiology Part C: Toxicology \& Pharmacology. 2002; 132: 3752-.

21. Morsy MA, Heeba GH, Abdelwahab SA, Rofaeil RR. Protective effects of nebivolol against cold restraint stress-induced gastric ulcer in rats: Role of no, ho-1, and cox-1, 2. Nitric Oxide 2012; 27: 117122-.

22. Wang GZ, Huang GP, Yin GL, Zhou G, Guo CJ, Xie CG, Jia BB, Wang JF. Aspirin can elicit the recurrence of gastric ulcer induced with acetic acid in rats. Cellular Physiology and Biochemistry 2007; 20: 205212-

23. Best R, Lewis DA, Nasser N. The antiulcerogenic activity of the unripe plantain banana (musa species). British Journal of Pharmacology 1984; 82: 107116-.

24. Onasanwo SA, Emikpe BO, Ajah AA, Elufioye TO. Anti-ulcer and ulcer healing potentials of musa sapientum peel extract in the laboratory rodents. Pharmacognosy Research 2013; 5: 173.

25. Chattopadhyay I, Bandyopadhyay U, Biswas K, Maity P, Banerjee RK. Indomethacin inactivates gastric peroxidase to induce reactive-oxygenmediated gastric mucosal injury and curcumin protects it by preventing peroxidase inactivation and scavenging reactive oxygen. Free Radical Biology and Medicine 2006; 40: 13971408-.

26. Sabiu S, Garuba T, Sunmonu T, Ajani E, Sulyman A, Nurain I, Balogun A: Indomethacininduced gastric ulceration in rats: Protective roles of spondias mombin and ficus exasperata. Toxicology Reports 2015; 2: 261267-.

27. Kumar MM, Joshi M, Prabha T, Dorababu M, Goel R. Effect of plantain banana on gastric ulceration in niddm rats: Role of gastric mucosal glycoproteins, cell proliferation, antioxidants and free radicals. Indian Journal of Experimental Biology 2006; 44: 292299-.
28. Agarwal P, Singh A, Gaurav K, Goel S, Khanna H, Goel R. Evaluation of wound healing activity of extracts of plantain banana (musa sapientum var. Paradisiaca) in rats. Indian journal of experimental biology 2009; 47(1):3240-.

29. Goel R, Gupta S, Shankar R, Sanyal A. Antiulcerogenic effect of banana powder (musa sapientum var. Paradisiaca) and its effect on mucosal resistance. Journal of Ethnopharmacology 1986; 18: 3344-.

30. Laine L, Takeuchi K, Tarnawski A. Gastric mucosal defense and cytoprotection: bench to bedside. Gastroenterology 2008; 135(1): 41-60.

31. Repetto M, Liesuy S. Antioxidant properties of natural compounds used in popular medicine for gastric ulcers. Brazilian Journal of Medical and Biological Research 2002; 35: 523534-.

32. Singh P, Dutta SR, Guha D. Gastric mucosal protection by aegle marmelos against gastric mucosal damage: Role of enterochromaffin cell and serotonin. Saudi journal of gastroenterology: official journal of the Saudi Gastroenterology Association 2015; 21: 35.

33. Anna N, Salvatore C, Laura S . Apoptosis, Necrosis, and Necroptosis in the Gut and Intestinal Homeostasis. Mediators Inflamm 2015; 2015: 250762 .

34. Vasconcelosa PCP, Andreob MA, Vilegasb W, Hiruma-Limaa CA, Pellizzona CH. Effect of Mouriri pusa tannins and flavonoids on prevention and treatment against experimental gastric ulcer. Journal of Ethnopharmacology 2010; 131:146-153

35. Mohan K, Manish KG, Amit S, Raj KG. Healing effects of Musa sapientum var. paradisiaca in diabetic rats with co-occurring gastric ulcer: Cytokines and growth factor by PCR amplification. BMC Complementary and Alternative Medicine 2013; 13 (1):305.

36. Ganguly K, Sharma AV, Reiter RJ, Swarnakar S. Melatonin promotes angiogenesis during protection and healing of indomethacin-induced gastric ulcer: role of matrix metaloproteinase-2. J. pineal Res. 2010; 49: 130140-.

37. da Silva M S, de Almeida ACA, de Faria FM, Luiz-Ferreiraa A, da Silva MA, Vilegas W, Pellizzonc $\mathrm{CH}$, Britoa AR. Abarema cochliacarpos: Gastroprotective and ulcer-healing activities. Journal of Ethnopharmacology 2010; 132: 134-142.

38. Jung MK, Nayoung K, Bongcheol K, Joo HK, Bong YL, Ji Hyun P, Mi Kyoung L, Hye SL, Joo SK, Hyun CJ, In Sung S. Enhancement of Gastric ulcer healing and angiogenesis by Cochinchina Momordica seed extract in rats. J Korean Med Sci 2010; 25: 87581-. 
Safaa $S$.

39. Rosida H, Sukardiman, Junaidi K. The increasing of VEGFexpression and re-epithelialization on dermal wound healing process after treatment of banana peel extract (Musa Acuminata Colla). International Journal of Pharmacy and Pharmaceutical Sciences 2014; 6 (11): 427430-.
40. Wallace JL, Devchand PR. Emerging roles for cyclooxygenase-2 in gastrointestinal mucosal defense. British Journal of Pharmacology 2005; 145(3): 275-282. 
الملخص العربى

تأثير الموز علي تلف غثاء المعدة المخاطي المستحث باستخدام عقار الاندوميثاسين علي الجيثي

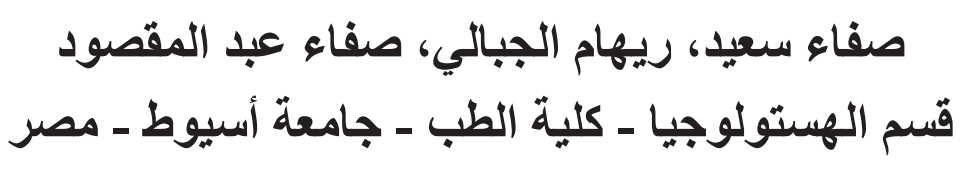

المقدمة: تعتبر مضادات الالتهاب اللا ستيرويدية من أكثر الأدوية التي تستخدم.ولكن يعد تلف المعدة من أكثر الأثار الجانبية

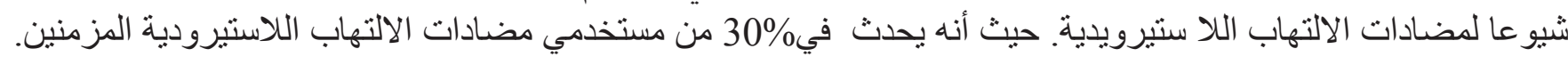

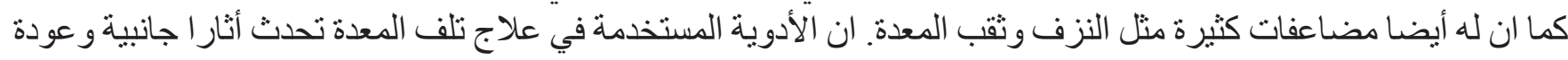

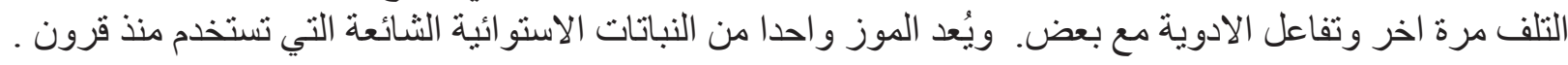

هدف الدراسة: تحديد دور الموزفي منع و علاج تلف المعدة المستحث باستخدام مضادات الالتهاب اللا ستيرويدية.

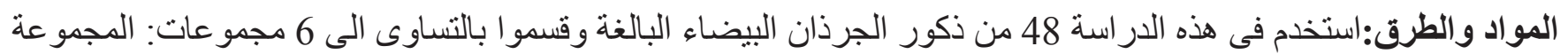

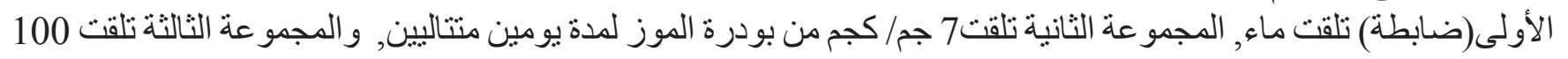

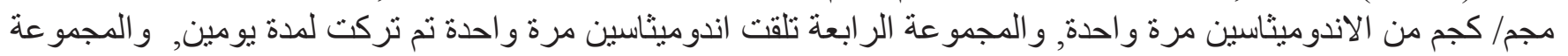

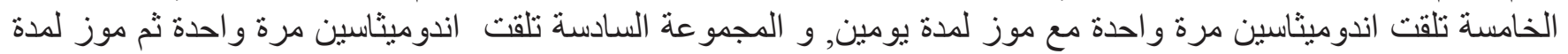

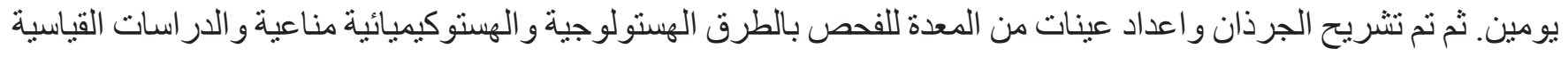
و التحليل الاحصائي.

النتائج: بفحص عينات مجمو عة الاندو ميثاسين (III) لوحظ جروح بالغشاء المخاطي وشر ائط نزفية وتقشير النسيج الطلائي وفقدان النظام

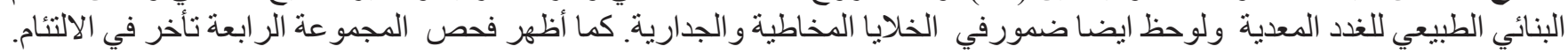

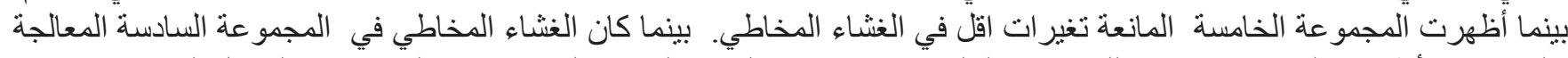

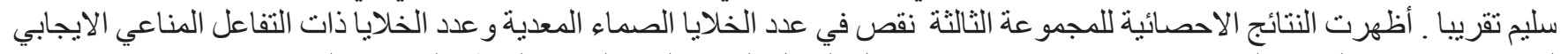

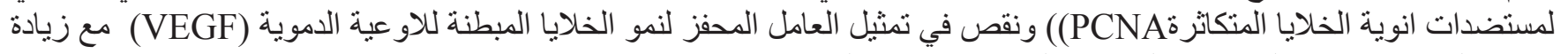
ذات دلالة احصائية في المجمو عة السادسة بالمقارنة مع باقي المجمو عات المعات.

الخلاصة: ان الموز يزيد من سرعة التئام الغشاء المخاطي المعدي التالف المستحث بعقار الاندوميثاسين ـ وقد كان تأثيره كعلاج اكثر

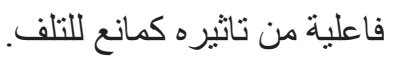

